NBER WORKING PAPER SERIES

\title{
ARE IDLE HANDS THE DEVIL'S WORKSHOP? INCAPACITATION, CONCENTRATION AND JUVENILE CRIME
}

\author{
Brian A. Jacob \\ Lars Lefgren \\ Working Paper 9653 \\ http://www.nber.org/papers/w9653 \\ NATIONAL BUREAU OF ECONOMIC RESEARCH \\ 1050 Massachusetts Avenue \\ Cambridge, MA 02138 \\ April 2003
}

We would like to thank the Tom Zelenock at ICPSR and Howard Snyder at NCJJ for help with the NIBRS data. Jenny Huang, Suzann Dickman, Joseph Price, and Paul Anderton provided excellent research assistance. We thank Sue Dynarski, Christopher Jencks, Steve Levitt, Jens Ludwig, Erzo Luttmer, Bridgitte Madrian, Anne Piehl, and seminar participants at Harvard, MIT, University of Texas, BYU and NBER for helpful feedback. All remaining errors are our own. The views expressed herein are those of the authors and not necessarily those of the National Bureau of Economic Research.

(C)2003 by Brian A. Jacob and Lars Lefgren. All rights reserved. Short sections of text not to exceed two paragraphs, may be quoted without explicit permission provided that full credit including Cnotice, is given to the source. 
Are Idle Hands the Devil's Workshop? Incapacitation, Concentration and Juvenile Crime Brian A. Jacob

NBER Working Paper No. 9653

April 2003

JEL No. I0, I2, H4

\section{ABSTRACT}

This paper examines the short-term effect of school on juvenile crime. To do so, we bring together daily measures of criminal activity and detailed school calendar information from 29 jurisdictions across the country, and use the plausibly exogenous variation generated by teacher in-service days to estimate the school-crime relationship. We find that the level of property crime committed by juveniles decreases by 14 percent on days when school is in session, but that the level of violent crime increases by 28 percent on such days. These results do not appear to be driven by inflated reporting of crime on school days or substitution of crime across days. Our findings suggest that incapacitation and concentration influence juvenile crime - when juveniles are not engaged in supervised activities, they are more likely to engage in certain anti-social behaviors; at the same time, the increase in interactions associated with school attendance leads to more interpersonal conflict and violence. These results underscore the social nature of violent crime and suggest that youth programs - particularly those with no educational component such as midnight basketball or summer concerts - may entail important tradeoffs in terms of their effects on juvenile crime.

Brian A. Jacob

John F. Kennedy School of Government

79 JFK Street

Cambridge, MA 02138

and NBER

brian_jacob@harvard.edu
Lars Lefgren

Department of Economics

Brigham Young University

130 Faculty Office Building

Provo, UT 84602-2363

lefgren@byu.edu 


\section{Introduction}

Juvenile crime touches millions of people in the United States each year, imposing substantial costs on society. In 1997, law enforcement officials arrested 2.8 million people under the age of 18, accounting for one in five of all arrests that year. Homicide is the second leading cause of death for youth ages 15 to 24; and juveniles are twice as likely as adults to be victims of serious violent crime and three times as likely to be victims of assault (Snyder and Sickmund 1997). Violence in schools and neighborhoods may also sharply reduce human capital investment by potential victims (Grogger 1997). Economists estimate that expenditures on criminal justice and private protection draw $\$ 175$ billion away from other productive uses each year (Anderson 1999). Similarly, the cost to society of allowing one youth to leave high school for a life of crime and drug abuse is estimated to range from $\$ 1.7$ to $\$ 2.3$ million (Snyder and Sickmund 1999, 82). From the perspective of the juvenile, incarceration is associated with a 1030 percent decrease in earnings (Grogger 1992, 1995; Waldfogel 1994; Freeman 1995; Kling 1997; Western 2001).

For these reasons, researchers have long sought to better understand the determinants of juvenile crime. Studies have suggested a variety of factors related to juvenile crime, including age (Blumstein et. al. 1986), gender (Wilson and Hernstein 1985), family background (Mocan and Rees 1999, Levitt and Lochner 2001), parenting quality (Daag 1991, Sampson and Laub 1993), economic opportunities (Grogger 1998, Lochner 1999) and the severity of punishment (Levitt 1998). Yet the factors underlying juvenile crime patterns and trends remain largely unexplained (Levitt and Lochner 2001).

It is often suggested that one way to reduce juvenile crime is to lengthen the school day or school year and/or to provide activities for young people when school is not in session. The 
implicit notion behind such program-oriented solutions to juvenile crime is a belief in the importance of incapacitation - that "idle hands are the devil's workshop" and that keeping kids busy will keep them out of trouble. Advocates of after-school and other youth programs frequently claim that juvenile violence peaks in the after-school hours on school days and in the evenings on non-school days. Indeed, as we can see in Figure 1, violent crime does in fact follow this pattern. ${ }^{1}$

While the intuition behind such policy prescriptions is sensible, the actual short-term effect of school or youth activities on juvenile crime is far from clear. First, there is no definitive evidence on the causal impact of youth programs on crime (Sherman 1997). Second, the studies of the timing of juvenile crime tend to look within the day, but do not address the level of crime across days. Implicitly, proponents of after-school program believe that lengthening the school day would lower crime during the afternoon without increasing violence during other periods. However, the fact that 57 percent of violent juvenile crime during the entire year occurs on the 180 days school is in session (Snyder and Sickmund 1999, 57) suggests that there is an association between school and increased juvenile violence. Finally, these studies do not consider property crimes or other non-violent crimes.

In this paper, we carefully examine the relationship between school and juvenile crime. This effort will not only help us to better understand the determinants of juvenile delinquency, but also provide some insight regarding the potential impacts of policy initiatives such as lengthening the school day/year or introducing new youth activities. Note that when we refer to the effect of school, we mean a short-run effect that is likely driven by day-to-day changes in the desire and opportunity to commit crime. We do not examine the longer-term impact of

\footnotetext{
${ }^{1}$ Snyder and Sickmund (1999) first documented this pattern using 1991-1994 NIBRS data.
} 
educational attainment on criminal activity that may operate through changes in the returns to legitimate work, the financial or psychic rewards of crime, or preferences. There is a relatively well-developed literature on this latter topic. See, for example, Witte (1997), Lochner (1999) and Lochner and Moretti (2001).

To do so, we bring together data on schooling and criminal activity from a number of cities and towns across the United States. To measure criminal activity, we use daily level reports of criminal incidents, victimizations and arrests for 29 jurisdictions from 1995 to 1999 collected by the Bureau of Justice Statistics and compiled in the National Incident-Based Reporting System (NIBRS). To this crime data, we merge school calendar data for each year collected from the school districts within each reporting jurisdiction. The school calendar data provide precise information on when school is in session and the reason that students do not have school (e.g., summer, school break, national holiday or teacher in-service training), allowing us to exploit the considerable variation in school terms across cities and over time.

The primary difficulty in estimating the effect of school on crime is that school days are not randomly distributed across the year. Crime may be systemically higher or lower on days when school is not in session for a variety of unrelated reasons. For example, there is evidence that violent crime increases with temperature and on weekends (Anderson et. al. 2000). We address this by focusing on the variation generated by teacher in-service days - days on which students do not attend school that teachers use for professional development or planning purposes. We argue that these days are extremely unlikely to be correlated with any factors influencing the level of criminal activity. By including a series of fixed effects for city*month*year and day of the week, we account for other unobservable time and location specific factors that may be correlated with school and juvenile crime. 
We find that the level of property crime committed by juveniles decreases by roughly 14 percent on days when school is in session. In contrast, we find that the level of violent criminal offenses among juveniles increases by roughly 28 percent on school days. We find little evidence that crime changes on the days immediately before or after school closings, suggesting that the changes in crime are not simply a result of substitution across days. And several facts suggest that the apparent perverse effect of school on violence is not simply due to heightened reporting by school personnel. The estimates for aggravated assault, a serious violent crime that is more likely to be reported regardless of the time or location of occurrence, are close to those for simple assault, a relatively minor offense that often goes unreported. ${ }^{2}$ The pattern of results is similar if one excludes all crimes that take place in school or during school hours. Finally, independent data from the National Crime Victimization Survey (NCVS) indicates that crimes occurring at school are actually less likely to be reported than those occurring elsewhere.

This analysis provides some valuable insight into the nature and motivation of juvenile crime. In particular, it confirms that when juveniles are not provided with a supervised environment, they are likely to engage in anti-social behavior that manifests itself in increased property crime. However, it also suggests that the degree of interaction among youth plays a significant role in the level of juvenile violence, highlighting the potentially volatile nature of juvenile interactions and the social nature of juvenile violent crime.

This analysis also has several implications for policy. First, it seems clear that policies that introduce after-school programs, lengthen the school year or provide other programs for young people will help mitigate the number of property and other opportunistic crimes committed by juveniles. However, our results suggest that such policies have important

\footnotetext{
${ }^{2}$ Ideally, we would like to look at very serious crimes such as murder and rape. These crimes are extremely rare, however, making it impossible to estimate the effect of school on these incidents with precision.
} 
tradeoffs in relation to personal or violent crime. Because they increase the concentration of young people in certain locations, they run the risk of raising the number of altercations that turn violent.

The remainder of the paper is structured as follows. Section 2 presents a conceptual framework for understanding and identifying the school-crime relationship. Section 3 describes the data used in this analysis. Section 4 presents the results and Section 5 concludes.

\section{Understanding and Identifying the School-Crime Relationship \\ 2.1 Conceptual Framework}

There are at least three channels through which school might influence juvenile crime in the short-run. The implicit assumption behind proposals that seek to mitigate juvenile crime by instituting after-school or other youth programs is that school has an incapacitation effect - that is, it serves to keep kids busy and off the streets. In this view, by engaging students in structured activities and monitoring them, school will deter adolescents from committing crime. ${ }^{3}$ At the same time, however, school increases the geographic concentration of juveniles, thereby increasing the number of potentially volatile interactions among youth. To the extent that juvenile violent crime is at least partly a function of the number of such interactions, school might be expected to raise the level of juvenile violent crime. Note that this concentration effect need not manifest itself only during the school day or on school property. One might imagine two students getting into an altercation during school and then "settling" it after school or later that evening in a nearby park or different neighborhood. While the incapacitation effect will influence property as well as violent crime, the concentration effect will only impact violent

\footnotetext{
${ }^{3}$ Note that this argument does not make any claims about the long-term value of schooling itself. Any activity that engages and monitors youth might have the same incapacitation effect.
} 
crime. Finally, school may facilitate the coordination of crime among juveniles. That is, the increased concentration of juveniles may decrease the cost of planning crimes, which may in turn increase the observed level of juvenile crime. While this coordination effect is likely to apply to both property and violent crime, we do not find evidence of it below, and thus focus our discussion on the incapacitation and concentration effects. ${ }^{4}$

This framework suggests that one must (a) consider violent and property crime separately and (b) clearly distinguish between the timing and the level of crime. The fact that violent crime rates spike in the late afternoon on school days does not imply that the absence of school increases crime, but may simply reflect the effect of school on the timing of violence within the day. The reasoning above implies that school will indeed decrease property crimes but may actually increase violent crime. Because we examine the daily incidence of crime as opposed to the timing of crime (on which previous research has focused), we are able to test these implications.

Note that this framework can be applied to schooling changes on the extensive margin (e.g., increasing the number of school days during the year by shortening the summer break) as well as the intensive margin (e.g., increasing the length of the school day by instituting an afterschool program). It is also worth noting that school days could be more violent than non-school days even if increasing the duration of the school day reduces crime on the margin. The intuition here can also be used to better understand the potential effects of other youth programs, activities or neighborhood amenities (e.g., parks, recreation centers, midnight basketball games). To the extent that these opportunities attract a number of juveniles to the same location, they will

\footnotetext{
${ }^{4}$ Coordination necessarily implies that two or more offenders are involved in the commission of a crime. If school were important for the coordination of crimes, we would expect for school to have a more positive (less negative) effect on the incidence of crimes with multiple offenders. In section four, we see that this is not the case.
} 
increase the number of interactions between youth, thereby raising the potential number of conflicts and violent incidents.

\subsection{Identification Strategy}

We are interested in examining the impact of school on juvenile crime, a relationship that can be captured by the following simple equation:

$$
\text { JuvenileCrime }_{\text {dmyc }}=\alpha+\delta\left(\text { NoSchool }_{\text {dmyc }}\right)+\varepsilon_{\text {dmyc }}
$$

where JuvenileCrime is a measure of criminal activity on day $d$, in month $m$ and year $y$, in city $c$, and NoSchool is a binary variable that takes on a value of one when school is not in session and zero otherwise.

If the variable $\mathrm{NoSchool}$ is uncorrelated with the error term in equation (1), then $\delta$ provides an unbiased estimate. However, it is likely that school days share certain unobservable characteristics that are correlated with the level of criminal activity. Saturday, for example, is typically not a school day. Insofar as more people are out shopping and at social events on weekends, the benefits of crime might be greater, which would tend to bias our estimates upwards. This is true for the summer days as well since crime rates typically rise with the temperature (Anderson et. al. 2000, Jacob and Lefgren 2002). Summer may also be atypical in that it is a time that families frequently go on vacation—changing the scope and venue of juvenile criminal activity. Juvenile crime rates are generally lower on holidays, presumably because benefit of criminal activity decreases as people are at home with family and the opportunity cost for potential criminals increases insofar as they are attending holiday celebrations of their own. This would tend to bias our estimates downwards. 
We address these endogeneity concerns by exploiting variation in the school term generated by teacher in-service days. These are days that students do not attend school and that teachers use for professional development, teacher conventions, planning, or parent-teacher conferences. Table 1 illustrates the distribution of teacher in-service days by city. The first row shows the average across all in-service days in all cities and years. We see that districts have an average of 3.67 in-service days per year, although some have as few as one and others have as many as eight in any given year. Nearly 50 percent of in-service days occur on Fridays, with Mondays and Thursdays being the next most common days. Half of the in-service days take place from September to November, with the other half equally distributed across the Winter and Spring months.

While the purpose of in-service is to provide teachers with time to focus on administrative or professional tasks, districts occasionally schedule these days to coincide with school holidays (perhaps to provide a longer break for students and teachers). For example, some districts schedule in-service days on the Wednesday before Thanksgiving, or the Friday before President's Day. Because one might be concerned that juvenile crime would be different on such days for unrelated reasons, we exclude these in-service days from our main analysis. More specifically, we exclude in-service days that fall within seven days of a holiday observed by the district or on a holiday observed by other districts (e.g. some districts hold in-service days on Veteran's Day). Such days are reclassified as breaks. In addition, we classify early release in-service days as half-days, but not in-service days. We do so because the structure of school tends to be very different on half-days (e.g., these days are often reserved for assemblies or field- 
trips), making it difficult to interpret the effects of crime on half-days. ${ }^{5}$ We later show that our results are not particularly sensitive to these specification choices.

The second row in Table 1 shows the average for the remaining in-service days in all cities and years, referred to as the analysis sample. While the average number of days drops by roughly 1.5 , the distribution of in-service days across day of the week and season is roughly the same. The following rows in show the results for each of the 29 cities separately. It is clear that there is considerable variation across cities in the number of in-service days, with cities like Aurora, $\mathrm{CO}$ and Des Moines, IA scheduling roughly four in-service days per year while cities in the same state such as Colorado Springs and Iowa City offer roughly two days per year. There is also significant variation within city over time. ${ }^{6}$

While teacher in-service days provide the most convincing source of exogenous variation for identifying the school-crime relationship, there are several other instances in which students do not attend school that warrant investigation. Holidays and summer vacation are the two most obvious reasons that students do not attend school. Holidays include days such as Thanksgiving, Christmas, Memorial Day and Labor Day. While both days are clearly endogenous, we include them because this allows us to examine potential displacement and understanding the relationship is interesting.

Finally, there are non-school days that do not fit into any of the previous categories. These school breaks are quite diverse in timing and purpose, ranging from days near holidays such as the Friday following Thanksgiving to isolated vacation days in February or March associated with mid-winter or spring breaks provided in many districts. We divide these break

\footnotetext{
${ }^{5}$ These days also occur most frequently at the start and end of school and before breaks and holidays.

${ }^{6}$ Note that Westminster, CO has no in-service days in this sample, due to the fact its fall in-services are generally half-day and its spring in-services are generally the Friday preceding MLK and/or President's Day. While Westminster does not contribute to the identification of our estimates of the in-service coefficient, it does help us to estimate the other covariates with greater precision.
} 
days into two distinct groups-idiosyncratic breaks and common breaks. We define idiosyncratic breaks as those non-school vacation days that fewer than 30 percent of the districts have off and common breaks as those days that at least 30 percent of the districts have off. In practice, this means that days such as Friday following Thanksgiving, the days surrounding Christmas and New Year's are classified as common breaks while days such as mid-winter and spring break or other isolated vacation days are classified as idiosyncratic breaks. Although we would expect common breaks to resemble holidays, we might expect idiosyncratic breaks to provide another plausibly exogenous source of variation with which to verify our baseline school-crime relationship.

Hence, our final specification is analogous to the following:

$$
\begin{aligned}
\text { JuvenileCrime }_{\text {dmyc }}= & \alpha+\delta_{1}\left(\text { Inservice }_{\text {dmyc }}\right)+\delta_{2}\left(\text { Idiosyncratic_Break }_{\text {dmyc }}\right)+ \\
& \delta_{3}\left(\text { Common_Break }_{\text {dmyc }}\right)+\delta_{4}\left(\text { Holiday }_{\text {dmyc }}\right)+\delta_{5}\left(\text { Summer }_{\text {dmyc }}\right)+ \\
& \gamma\left(\text { HalfDay }_{\text {dmyc }}\right)+(\text { DayofWeek }) \Gamma+(\text { CYM }) B+\varepsilon_{\text {dmyc }}
\end{aligned}
$$

where In-service, Idiosyncratic_Break, Common_Break, Holiday and Summer are binary variables that are defined above, DayofWeek is a set of fixed effects for the day of the week, and CYM is a vector that includes fixed effects for the city*year*month. ${ }^{7}$ HalfDay is a binary variable that takes on the value of one when students are in school for a half-day for any reason. The fixed effects for city*year*month fixed effects control for any unobserved time or location specific factors that may be correlated with school and crime. The day-of-week dummies account for the fact that criminal activity may be greater, for example, on Fridays than on Mondays. ${ }^{8}$

\footnotetext{
${ }^{7}$ This subsumes all factors that do not vary within a given month and district. Note that in our sample there are not multiple school districts within a NIBRS jurisdiction.

${ }^{8}$ Saturdays and Sundays to not contribute to the identification of our in-service coefficient. We keep these days in the sample because (a) it is necessary in order to examine the displacement issue and (b) because some readers may be interested in seeing how juvenile crime varies from weekdays to weekends.
} 
Using a specification of the type described above, identification is achieved in the by comparing, for example, the level of crime on a Friday that is an in-service day with the level of crime on other Fridays in the same district and during the same month when school is in session. The use of district*year*month fixed effects control for all differences across districts, even if these difference vary from month to month. This ensures our estimates are not biased if some districts have more in-service days than others. The day-of-week fixed effects ensure that our estimates are not biased by the fact that in-service days are not randomly distributed over the week.

\subsection{Temporal Displacement}

Even if our results are driven by exogenous variation in school attendance, it is possible that school is not changing the level of criminal activity in aggregate, but merely shifting the time of occurrence. For example, a juvenile who is planning to steal something from the neighborhood store may find it more convenient to do so on a day that he has off from school. Similarly, the youth planning to take revenge on a rival may choose to do so on a school day because he knows the other youth will be nearby or because he wants others to witness the attack. In both cases, our estimates of the school-crime relationship would not capture changes in the total amount of crime over a longer period.

We adopt two strategies to examine whether school is merely displacing juvenile crime.

First, we examine the level of juvenile crime on the days just before and just after school breaks, holidays, and teacher in-service days. If juveniles simply saved all of their grudges, vendettas and other violent acts for days when school was in session, one might expect there to be unusually high levels of crime on the days just before or after school was not in session to 
compensate for the unusually low levels of violent crime on non-school days. Similarly, if juveniles shifted property crimes to non-school days, one would imagine the level of property crimes to be somewhat lower than usual in the periods surrounding days when school was not in session. Second, we replicate our analysis using weeks as the unit of analysis rather than days. If teacher in-service days merely caused adolescents to shift the timing of criminal activity, we would not expect the relationship between in-service days and weekly crime to be much smaller (or non-existent) than relationship observed using daily crime measures. As discussed in greater detail below, we find no evidence that juvenile violent crime is displaced. We find that some evidence that juvenile property crime may be displaced partially, although school still appears to have an aggregate effect. ${ }^{9}$

\section{Data}

This analysis requires a unique combination of detailed information on schooling and criminal activity. For information on criminal activity, we rely on the data provided in the National Incident-Based Reporting Systems (NIBRS). NIBRS data is crucial for our analysis since it is the only (to our knowledge) large-scale dataset that provides information on reported crimes and arrests on a daily basis. The NIBRS data is attractive for a number of other reasons as well. First, the age of the victim and offender are reported. This allows us to focus on crimes committed by and against juveniles. Second, the dataset reports the nature of the crime. Thus we can examine the effect of school attendance on different types of crime. Third, the data set

\footnotetext{
${ }^{9}$ Theoretically, one might extend this second strategy to examine the effect of the total number of school days in a year on the crime during that year. However, it is quite difficult to find sufficient exogenous variation in the length of the school year to provide precise estimation with this strategy. Almost all school districts have school in session for roughly 180 days per year. Moreover, the factors that influence the length of the school year in practice such as adverse weather conditions (e.g., snow days) may have an independent effect on the incidence of crime. Teacher strikes provide another potential source of useful variation, but are so rare (and limited to a select subset of districts) that they cannot be used to generate precise estimates.
} 
reports the time and location of crimes. With this information we are able to investigate the effect of schooling on the time and venue of criminal activity in addition to its level. Finally, NIBRS contains information on enough jurisdictions to lend statistical power to the analysis.

The primary disadvantage of NIBRS is that it only includes information on jurisdictions that have agreed to participate in the system, unlike the Uniform Crime Reports, a monthly compilation of criminal activity collected by the FBI to which all law enforcement agencies throughout the country report. In the first year of our sample, 1995, only 1,255 jurisdictions participated in NIBRS compared with 18,643 that reported data for the UCR. By 1999, 2,852 out of 19,659 jurisdictions were participating in NIBRS.

For the purpose of our study, we chose participating cities with the largest populations. We focus on cities because rural or suburban NIBRS jurisdictions are often served by multiple school districts. The choice of large jurisdictions maximizes the power of our estimates and facilitated the collection of school calendar data. ${ }^{10}$ We ultimately ended up with 29 jurisdictions because the vast majority of participating NIBRS jurisdictions are extremely small towns or rural/suburban jurisdictions. ${ }^{11}$ We drop roughly 2.6 percent (about 1000 city-days) of the observations due to missing or incorrectly reported crime data.

While our sample is by no means representative of the nation, Table 2 shows that our analysis does include a reasonably diverse collection of jurisdictions that appears to reflect the nation along a number of dimensions. Indeed, the percent white, black, Hispanic and Asian in our sample cities is virtually identical to the nation as a whole. The same is true in terms of the

\footnotetext{
${ }^{10}$ Because we include city*month*year fixed effects, cities with extremely small populations and therefore a low incidence of crime contribute very little to the estimation.

${ }^{11}$ Of the 2,852 jurisdictions that participated in NIBRS in 1999, 34 percent represented county and state police agencies. Of the remaining jurisdictions (city and town police departments), only 1.5 percent (28 jurisdictions) had over 100,000 inhabitants. Only 45 jurisdictions had between 50,000 and 100,000 inhabitants. Seventy-four percent of jurisdictions had fewer than 10,000 inhabitants. The fact that most participating jurisdictions are quite small reflects the fact that there are many more small towns than large cities nationally.
} 
fraction of single-parent households and the fraction of the population aged 10-19. The crime rate in our sample jurisdictions is considerably higher than the national average, although this is largely due to the fact that we are only looking at cities while the national averages contains suburbs and rural areas with significantly lower crime rates. The average jurisdiction size in our sample is $149,414^{12}$, ranging from towns such as Logan, UT and Nampa, ID with populations of 40,849 and 42,737 respectively to relatively large cities such as Austin, TX and Colorado Springs, $\mathrm{CO}$ with populations of 560,389 and 357,741 respectively. Moreover, the cities in our sample are spread throughout the country, with one-quarter to one-third of the sample coming from the South, Midwest and West. (A complete list of the jurisdictions and years included in the analysis can be found in Appendix A.)

It is worth noting that the fact that our sample is not nationally representative will not affect the internal validity of the estimates. The use of city*year*month fixed effects implies that all identification is being achieved by high frequency variation within a school district. As in all such cases, the external validity of the estimates depends on the similarity between the analysis sample and the sample to which one would like to make an inference. Because of the diversity of our sample, we believe that inferences can be made to most cities in the U.S.

To obtain information on schooling, we merge the NIBRS data with detailed school calendar data that we obtained by calling individual school districts. The school calendars provide precise information on the days that students have off from school and the reason (e.g., summer break, national holiday, teacher in-service training, etc.). This not only allows us to minimize measurement error, but also to exploit the considerable variation in school calendars across cities and over time within a city.

\footnotetext{
${ }^{12}$ Some of the largest cities are in our sample for a relatively short period of time. Weighting cities by the number of days they are in our sample and taking into account yearly changes in population, the average city size is about 119,326 .
} 


\subsection{Measures of Criminal Activity}

Having described our data sources, it is important to describe our measures of criminal activity. As noted above, NIBRS provides information on both incidents and arrests. The primary advantage of arrest data for our purposes is that it allows one to determine the offender age with certainty. However, because not all incidents result in an arrest, this data will tend to understate the true level of criminal activity and provide much less information for our estimation. In order to maximize the power of our analysis, we use incident data in our main specifications, including all incidents for which it is possible to identify the age of the offender. Thus our dependent variable in the preferred specifications is the recorded number of juvenile offenders within a city on a given day.

The main concern with focusing on offender data involves the prevalence of missing age information. In our sample, only 10 percent of violent crime incidents are missing information on the offender's age whereas roughly 59 percent of property crime incidents are missing this information. If offender age were missing at random, or in a way uncorrelated with the school term, it would not influence the consistency of our estimates. However, one might contend that offender age is less likely to be missing on school days perhaps because crimes take place right after school or near school premises and that police and potential victims are more cognizant of juveniles on such days. If this were true, our estimates might be biased. In the case of property crime - where missing data is the greatest concern — this suggests that school may decrease property crime even more than we find.

We address this concern in two ways. First, we estimate all of our models using arrest data, where we know the offender age with certainty, and find comparable results (see Table 11). 
Second, to explore whether age information appears to be missing at random, we estimate models similar to (2), but with the outcome variable being the fraction of reported incidents with no information on offender age. Because the nature of the crimes and degree of missing data varies significantly across crime type, we estimate separate models for violent and property crime. For both types of crime, we find neither statistically significant nor substantively important relationships between teacher in-service day, school breaks or summer vacation and the fraction of data that is missing offender age. ${ }^{13}$ This suggests that the missing offender information in incident reports is unlikely to seriously bias our findings.

Another concern involves the accuracy of the offender age information. Fortunately, the existence of arrest information linked to the incident reports provides us with a way to examine this issue. If the incident results in an arrest, the age of the arrestee is always collected. In our sample, roughly half of reported incidents include information on the offender. Of these incidents, roughly 48 percent result in arrests, which means that in about one-quarter of all reported incidents we have information on the offender's age as reported by witnesses or victims as well as the exact age of the suspect arrested for the offense, allowing us to check the accuracy of reported offender age. The correlation between reported offender age and actual arrestee age is roughly $0.97 .^{14}$ Moreover, of all of the offenders who were reported as juveniles (ages 5 to 17) by victims or witnesses, less than 3 percent were in fact 18 years or older (at the time of the incident) based on the arrest records, and nearly all of these 3 percent were 18 to 24 years old

\footnotetext{
${ }^{13}$ On national holidays, reported property crimes are more likely to be missing offender age information, but reported violent crimes are less likely to be missing offender age. This may be because a greater proportion of violent crime on holidays involves family members, or that property crime during the holidays includes a disproportionate number of home burglaries where the offender is rarely known. Regardless, this correlation is not problematic since we rely on teacher in-service days in our analysis. All of these results are available from the authors upon request.

${ }^{14}$ Because there may be more than one reported offender and/or arrestee per incident, we look at both the maximum and minimum ages, which also happen to have correlations of exactly 0.97 .
} 
according to arrest records. Virtually none of the offenders who were reported as 18 or older by victims or witnesses were actually younger than this based on arrest records.

A final concern — reporting bias—applies to both incident and arrest data. Both measures miss crime that goes unreported to the police and/or do not result in an arrest. As long as unreported crime is distributed randomly, this should not influence our estimates. However, if the likelihood a crime is reported is correlated with the school term, our results may be biased. We discuss this issue in greater length in the following section, providing evidence that reporting bias is not in fact driving our results. ${ }^{15}$

Table 3 provides descriptive statistics on the primary variables used in the analysis. We see that there are an average of 5.2 juvenile offenders for all serious offenses with a standard deviation of 5.7. The $25^{\text {th }}$ percentile is 1 and the $75^{\text {th }}$ percentile is 7 . There are no juvenile offenses in 6.5 percent of the city-days in our sample. Looking at data on the key independent variables, we see that 23 percent of the days in our sample consist of summer vacation, 3.1 percent consist of holidays, 2.8 percent are common breaks, 1.5 percent are idiosyncratic breaks and less than one percent are teacher in-service days.

\subsection{The Four " $W$ 's" of Juvenile Crime}

In seeking to understand the determinants of juvenile crime, it is useful to examine who commits juvenile crime, what crimes juveniles most often commit, and where and when juvenile crimes occur. Table 4 presents some basic descriptive statistics regarding juvenile offenders and their victims. We see that offenders are most likely to be white, male and between 15 and 17

\footnotetext{
${ }^{15}$ Others have used survey data to better measure the true level of criminal victimizations and to assess the degree of unreported crime. Unfortunately, victimization surveys do not provide sufficient coverage to test our hypothesis. They also suffer from the measurement error and biases inherent in self-report data.
} 
years of age. The victims of juvenile violent crime are generally other juveniles, with only onequarter of victims over the age of 24 .

Table 5 shows what types of crimes juveniles are most likely to commit. Among serious offenses (as defined by NIBRS), the most common crimes committed by juveniles are shoplifting, simple assault and vandalism, which account for nearly half of all crimes committed by juveniles. Larcency, drug violations, burglary, aggravated assault and motor vehicle theft account for an additional 30 percent of juvenile crime. Very serious violent crimes such as rape and murder account for a tiny proportion of juvenile crime (less than one percent of serious offenses). The bottom panel, which includes all offenses, indicates that the most common minor offenses (i.e., NIBRS Type B offenses) among juveniles include runaway, loitering, vagrancy, disorderly conduct and liquor law violations, which account for roughly 18 percent of all juvenile offenses.

Table 6 provides a snapshot of where juvenile crimes occur. The majority of thefts occur at stores or restaurants, reflecting the prevalence of shoplifting among juveniles. On school days, however, roughly 7 percent of thefts occur within school buildings and, in these cases, presumably involve one youth stealing from another. While over three-quarters of vandalism incidents take place in public places or residences, about 11 percent of all reported vandalism incidents on school days take place in school. Similarly, a substantial proportion of assaults and drug violations take place in school. On days when school is not in session, assaults and drug violations nearly always occur in public locations or individual residences.

Figure 1 shows the timing of juvenile crime on school and non-school days. We see that on school days, violent crime peaks at around 3 p.m., around the time that school gets out. The 
rate then declines steadily through the evening until midnight. ${ }^{16}$ On non-school days, violent crime rises gradually until the afternoon and then plateaus until after midnight. The timing of property crime appears similar on school and non-school days, with the incidence of crime rising gradually until early evening and then declining.

\subsection{Estimation Strategy}

From an econometric standpoint, it is important to use an estimation strategy that takes into account the nature of the data. While the simplest strategy is to estimate OLS models using the number of criminal incidents/offenders, this strategy has several problems. Because criminal incidents are positively skewed, it is common to transform the data using logs or log rates. However, because we are using daily data for individual cities and we are differentiating between adult and juvenile crime, there are a non-trivial number of zeros in the data, particularly when we focus on individual crime categories - complicating the use of log crime rates. In order to address these concerns, we estimate a negative binomial regression model (Greene 2000). The negative binomial model is a generalization of the Poisson regression model that allows for the variance of the outcome measure to differ from the mean, making it appropriate for count data with overdispersion. In order to accommodate the city*month*year effects in our model, we use the fixed effects negative binomial model developed by Hausman, Hall, and Griliches (1984). The coefficients represent the effect of the independent variables on the log of the mean incidence and can therefore be interpreted as being the approximate percentage effect of the independent variable on crime.

\footnotetext{
${ }^{16}$ The level of crime around midnight is somewhat inflated because of a tendency for law enforcement agencies to list midnight as the time of occurrence for a disproportionate number of crimes occurring from $11 \mathrm{pm}$ to $1 \mathrm{am}$. We thank Howard Snyder for bringing this point to our attention.
} 


\section{Results}

To get a sense of the underlying relationship between school and juvenile crime, it is useful to begin by looking at the raw data. Table 7 shows the mean number of juvenile offenders per 100,000 residents on school and non-school weekdays. For property crime, there is only a small difference between juvenile crime rates on school versus non-school days (3.5 versus 3.8). Insofar as summer vacations, national holidays and breaks are different than school days along a number of dimensions that may be independently related to criminal activity, we cannot interpret this difference as the causal effect of schooling. However, if we focus on our cleanest comparison— between teacher in-service days and school-days — juvenile property crime seems to be substantially higher when school is not in session (3.5 versus 4.4$)$. In contrast, the juvenile violent crime rate appears to be substantially lower on non-school days. For example, juvenile violent crime rates are roughly one-third lower on teacher in-service days compared with school days. Hence, the simple comparison of means suggests that school may reduce juvenile property crime, but actually increase juvenile violent crime.

One might be concerned, however, that other district- or time-specific factors could be driving this apparent relationship between school and crime. For example, school districts that schedule many teacher in-service days may differ systematically from other school districts, or the scheduling of breaks or in-service days may take place during times of the year, or days of the week that tend to have low (or high) crime. The following models attempt to control for such factors.

Table 8 shows the results of negative binomial regressions in which the dependent variable is the number of reported juvenile offenders. All regressions include a fixed effects for the day of the week and city*year*month fixed effects to account for static (or even slowly 
changing) differences between districts as well as changes in criminal activity due to the time of year or day of the week.

If we consider all crimes together, there does not appear to be a strong or convincing relationship between school and crime. In fact, the point estimate for teacher in-service days is essentially zero. When we consider violent and property crimes separately, however, a quite different picture emerges. The coefficients suggest that the level of juvenile property crimes is about 13 percent higher on teacher in-service days, suggesting that school decreases juvenile property crime. In contrast, the point estimates indicate that juvenile violent crime is roughly 32 percent lower on teacher in-service days, evidence that school actually increases juvenile violent crime. Exponentiating the coefficients to obtain exact effects suggests that in-service days are associated with 14 percent more property crime and 28 percent less violent crime. As mentioned earlier, school breaks unrelated to holidays and not common across districts may provide an additional source of exogenous variation in schooling. If this were the case, we would expect the coefficients on idiosyncratic break to resemble those on teacher in-service. We see that idiosyncratic breaks are associated with approximately a 15 percent increase in property crime and a 20 percent decline in violent crime among juveniles, confirming the school-crime relationships identified with the teacher in-service variable. ${ }^{17}$

Column 4 presents results for other serious crimes, which consist primarily of drugrelated offenses. The point estimate suggest that there is a modest positive relationship between school and drug crimes - that is, on teacher in-service days, the incidence of such crimes among juveniles decreases by approximately 10 percent. However, this effect is not statistically

\footnotetext{
${ }^{17}$ For simplicity in the remainder of the paper, we discuss the coefficient estimates as percentage effects with the understanding that these numbers are approximations, which should be exponentiated to obtain exact estimates.
} 
significant at conventional level. ${ }^{18}$ The final column examines minor offenses, which include disorderly conduct, loitering, and alcohol violations among others. The coefficient on teacher inservice suggests that school increases the incidence of these offenses by roughly 15 percent. Insofar as many of these offenses are most commonly committed in groups, these results are not surprising.

The other coefficients provide some additional insight into the nature and patterns of juvenile crime. Juvenile violent crime is substantially lower on holidays, common school breaks and during the summer while juvenile property crime only appears to decline on holidays. ${ }^{19}$ On half-days, we observe 16 and 10 percent more property and violent crime respectively, although the interpretation of these coefficients is not clear for the reasons discussed earlier. Weekends are associated with much less juvenile violent crime than other days of the week. In contrast, adult violent crime is much more common on weekends. Property crime is less common on Sundays and midweek than other days.

Table 9 presents similar estimates for individual offenses separately. For the sake of brevity, we report only the coefficients on in-service day. Among violent crimes, we see that school appears to have a similar negative effect on both simple and aggravated assaults, although the aggravated assault point estimates are less precisely estimated. With the exception of vehicle theft, the property crime results are all consistent with the general finding. On teacher in-service days, the percent of reported juvenile offenses increases 23 percent for burglary, 24 percent for shoplifting, 18 percent for vandalism, and 20 percent for robbery. Drug violations appear to

\footnotetext{
${ }^{18}$ The point estimate on idiosyncratic breaks is nearly identical, and when these variables are combined, the estimates are marginally significant.

${ }^{19}$ The lack of correlation between summer vacation and property crime might be because students are more likely to vacation with family or engage in other forms of summer recreation as opposed to committing crime. The small effect is largely driven by the fact that summer vacation appears to have a minimal effect on shoplifting. The incidence of other property crime, such as burglary, robbery, vandalism, and vehicle theft does increase during summer vacation.
} 
decrease when school is out, though the effect is insignificant. Curfew and loitering violations increase by 22 percent on teacher in-service days, but disorderly conduct among juveniles decreases by 51 percent.

\subsection{Temporal Displacement}

While the evidence above suggests that school influences the prevalence of juvenile crime on particular days, it is possible that school is merely causing juveniles to shift crime to other days and therefore does not effect the aggregate level of crime. Table 10 provides some evidence on this type of displacement. The top panel shows the results of a model that includes indicator variables for the three days immediately preceding and the three days immediately following all non-school days, in addition to all of the other covariates included in earlier models. If displacement were important, we would expect the coefficients on the leads and/or lags to be significant and to take on the opposite sign of the in-service variable. For violent crime, we see that while juvenile offenses decline by about 30 percent on teacher in-service days, there is no significant difference in the level of juvenile violence on the three days immediately before or after such days. Indeed, the coefficients for the leads and lags are all the same sign as the in-service variable, and a chi-squared test indicates that the sum of these coefficients is significantly different from zero. ${ }^{20}$ This suggests that school does indeed increase the level, and not simply the timing, of violent crime. For property crime, the coefficients on the lead and lag variables bounce from negative to positive, although none are statistically significant. The sum of the coefficients, however, is close to zero and is not statistically different from zero. This is

\footnotetext{
${ }^{20}$ Note that the non-linear nature of the model slightly complicates the interpretation of the sum of coefficients. It may be that the baseline rates of offending are different on the days preceding or following in-service. Thus the percentage effects are not perfectly comparable for the lags and leads of the in-service variable. This is not a problem with linear models (e.g. OLS), which give us the same results. Furthermore, our examination of weekly crime rates that we report next is not affected by this concern.
} 
consistent with displacement of property crime over the course of a week, but the lack of precision makes it difficult to draw strong conclusions.

The bottom panel of Table 10 presents the results of a model in which we examine the effect of in-service on crime aggregated over a longer time period in order to test for displacement. To do so, we sum the number of crimes over a seven-day period centered on Friday (the modal in-service day) and then use the same negative binomial regression framework to estimate the relationship between weekly crime and the fraction of the week that was an inservice day. ${ }^{21}$ We control for the fraction of the week composed of summer vacation, holidays, idiosyncratic and common breaks and half-days as well as fixed effects for city*month. This specification yields coefficients that are comparable to our baseline estimates. The point estimate for property crime indicates that increasing the fraction in-service from zero to one raises the weekly incidence of juvenile property crimes by roughly 27 percent (although the coefficient is only marginally significant). The corresponding effect for violent crime is statistically significant and represents a decrease of roughly 56 percent. Both of these effects are larger in absolute value than the corresponding one-day effects, suggesting that temporal displacement does not complicate the interpretation of our coefficients. In sum, there is no evidence of displacement in the case of violent crime and only weak evidence of displacement in the case of property crime.

\footnotetext{
${ }^{21}$ The negative binomial coefficients represent approximate percentage effects. If we simply used the sum of inservice days in a week as the dependent variable, we would expect a smaller coefficient than our baseline results because the same absolute effect of in-service days has a smaller percentage effect on weekly crime than on daily crime. Using the fraction of the week composed of in-service days accounts for this difference.
} 


\subsection{Sensitivity Analyses}

Table 11 presents the results from a number of different sensitivity analyses. Perhaps the most serious concern involves reporting bias. In particular, juvenile crime may be more likely to be reported on school days because of greater supervision on the part of school personnel or greater vigilance by law enforcement. ${ }^{22}$ For example, one could imagine that a relatively minor fight between adolescents would not come to the attention of authorities on non-school days, but on school days a teacher bring the incident to the attention of law enforcement. This differential reporting of criminal activity would lead us to overstate the deleterious effects of school on violent crime. On the other hand, it is possible that crimes committed by juveniles in or around school may be more likely to be handled by school personnel and therefore not come to the attention of the police, in which case our violent crime estimates may actually be too low.

The National Crime Victimization Survey (NCVS) provides an excellent forum to investigate this concern. The NCVS is an annual, nationally representative survey of roughly 50,000 households conducted by the Bureau of Justice Statistics in order to determine the "frequency, characteristics and consequences" of criminal victimization in the United States. The NCVS collects detailed incident level data about all reported and unreported criminal victimizations that allow one to determine, among other things, the age of the victim(s) and offender(s), the time and location of the offense, the type of crime(s) committed, and whether the crime was reported to law enforcement. Using NCVS data on all victimizations committed by juvenile offenders from 1992 to 2000, we find that reporting rates are actually lower for crimes committed at or near school. This is true not only for broad crime categories such as assault, theft or robbery, but also for much more detailed categorizations that distinguish offenses by

\footnotetext{
${ }^{22}$ Reporting bias is unlikely to be a large concern with crimes such as shoplifting and vandalism, which constitute the bulk of juvenile property crimes.
} 
their the severity (e.g., completed robberies with injury from serious assault, thefts of less than $\$ 10$, simple assault completed without injury, threatened verbal assault, etc.). ${ }^{23}$

Despite the findings from the NCVS data, it is nonetheless useful to examine the possibility of reporting bias in our analysis. One way to do so is to focus on serious crimes that are more likely to be reported to authorities regardless of the time or location of occurrence. The NCVS data indicate that aggravated assault (defined as an attack wherein the offender uses or displays a weapon, or the victim suffers obvious, severe or aggravated bodily injury) is substantially more likely to be reported than simple assault, the most common violent juvenile offense. Yet, row 2 in Table 11 shows that in-service days have approximately the same effect on aggravated assault as on all violent crime. ${ }^{24}$ Another way to address the issue of reporting bias is to examine the timing or location of juvenile crime within the school day. If schoolrelated reporting bias were driving the results, one would expect the effect to disappear if one looks only at crimes that take place during non-school hours or crimes that take place outside of school. Row 3 examines the number of offenders committing crimes during non-school hours (i.e., before 7 a.m. and after 3 p.m.). While the coefficients shrink somewhat, the pattern remains the same and the violent crime results are still strongly significant. Row 4 examines crimes that do not occur on school grounds. Note that this final specification reflects a very stringent test since it implicitly assumes that crimes reported at school would never have been reported had they occurred elsewhere. Still, we find the general pattern of results remains the same, although the coefficient on violent crime is significant at only the 10 percent level.

Together these results suggest that reporting bias is not driving the effects of school on crime that we identify here.

\footnotetext{
${ }^{23}$ Tables available from the authors upon request.

${ }^{24}$ As mentioned earlier, it would be even more convincing to examine extremely serious crimes such as rape and murder, but these crimes are too rare to provide useful estimates.
} 
In addition to the concentration and incapacitation effects of school, we mentioned that school might facilitate the coordination of crimes committed by multiple juveniles. If this were true, we would expect in-service days to affect committed by single juveniles differently than crimes committed by multiple youths. In particular, we would expect to in-service days to have a less positive or more negative effect on crimes committed by more than one juvenile offender. The estimates presented in rows 5 and 6 show that this is not the case.

Another concern is that the timing of in-service days may correspond to events that affect crime more generally. We investigate this omitted variable issue in several ways. First, row 7 shows estimation results of a falsification exercise in which we examine the effect of in-service days on adult crime. If the in-service coefficient simply reflected an important omitted variable, we would expect in-service days to be predictive of adult crime as well. We find that in-service days are not associated with any change in adult property or violent crime. The specification in row 8 examines the effect of in-service days on juvenile crime when we control for the incidence of adult crime. If in-service days were simply a proxy for the attractiveness of crime in a particular time or place, controlling for the adult crime rate should reduce the correlation between in-service days and juvenile crime. The coefficients, however, are very similar to our baseline estimates. Finally, the specification in row 9 shows that controlling for the mean temperature and daily precipitation — factors associated with the school calendar that have been shown to influence criminal activity—does not affect our in-service coefficients.

To the extent that victims or others who report an offense cannot accurately tell the age of the offender, the number of juvenile offenders may be measured with some error. If this measurement error is uncorrelated with the school calendar, our estimates will not be biased. However, one might believe that this measurement error is correlated with school being in 
session. For example, on days when it is generally known that school is off, such as Spring break, someone who witnesses an act of vandalism from the distance may be more likely to report that the offender was a "kid" because he or she knows that children are not in school. For this reason, the specification in row 10 uses the number of juvenile arrests-where we can be certain of the offender age - as the outcome variable. The violent crime estimates from this model are comparable to those in the baseline model, although the property crime results are smaller and no longer statistically significant. This suggests that this type of measurement error is not biasing our violent crime results, but may have a modest affect our results for property crime.

Another potential concern is that school may increase the number of juveniles involved in any given offense without actually increasing the number of offenses. This might be true if would be offenders recruit accomplices in school. In specification 11, we show results in which we focus on the number of offenses in which at least one juvenile is involved. These results are virtually identical to the baseline estimates.

In our baseline specification, days are measured in a typical fashion-from midnight to midnight. However, in considering the timing of daily activity, it may make more sense to think of crimes committed in the early morning hours (say $3 \mathrm{am}$ ) of Day 2 as having occurred during Day 1. Consider, for example, a group of adolescents committing a series of vandalism over an evening. Any acts they commit at 10 pm would count toward the total level of crime in Day 1 , but acts they commit three hours later at 1 am, during the same crime "spree," would count toward the level of crime in Day 2. The specification in row 12 shows that reclassifying early morning crimes to the previous day does not change our results. 
In our baseline specifications we have focused on the variation in school calendars most likely to be exogenous. The specification in row 13 shows that when we expand our definition of in-service to include all full-day in-service days during the school year, the coefficients are nearly identical to our baseline estimates. Row 14 combines our baseline measure of in-service days with our idiosyncratic break variable. The estimates are now slightly smaller in absolute value than our baseline estimates, though they are estimated much more precisely.

Because concerns have been raised about the fixed effect negative binomial model, ${ }^{25}$ we present results derived from alternative estimation techniques. In specification 15 , we estimate a Poisson regression model with the baseline covariates and fixed effects. The interpretation of the coefficients is the same as with our baseline estimates. Relative to our preferred specification, the effect of in-service days is somewhat smaller for property crime but very similar for violent crime. ${ }^{26}$ For specification 16, we use OLS to estimate the effect of in-service days on the number of offenders per 100,000 inhabitants. Note that the point estimates go in the expected direction and are significant for violent crime (though not property crime), even with a correction for possible heteroskedasticity. Dividing the coefficients by the mean daily incidence per 100,000 residents in our sample to obtain results that can be compared to the earlier models, we find that the OLS models indicate in-service increases property crime by 10 percent and reduces violent crime by 40 percent (the numbers presented in brackets in the table), quite similar to the baseline estimates.

\footnotetext{
${ }^{25}$ Allison and Waterman (2002) have criticized the fixed-effects negative binomial model developed by Hausman, Hall, and Griliches (HHG) (1984), arguing that it is not a "true" fixed-effects specification in that one can still estimate time-invariant covariates in this model (a point made by the authors in the original article). However, both sets of authors show that the HHG model yields similar results to a "true" fixed effect Poisson model, which should provide unbiased (though inefficient) estimates.

${ }^{26}$ The standard errors are incorrect in as much as there is over-dispersion in our data. While it is theoretically possible to correct the standard errors, this would involve estimating all of the individual fixed-effect coefficients. Given that we have more than 1000 fixed effects and a large data set, doing so is not feasible.
} 


\subsection{Who Wins and Loses as a Result of the Schooling Effects on Juvenile Crime}

Having demonstrated how crime varies across the school calendar, it is interesting to examine who wins and who loses as a result of these changes in juvenile crime. Table 12 presents estimates of the relationship between the number and type of reported victims of juvenile crime and the school term. Not surprisingly, the true beneficiaries of schooling in terms of juvenile property crime are adults and institutions (e.g., shops, stores, restaurants). We see that juveniles are no more or less likely to be victimized by other juveniles on teacher in-service days. In contrast, the number of adults who report being victimized by a juvenile for a property offense increases 16 percent on such days.

On the other hand, juveniles are the overwhelming beneficiaries of non-school days in terms of violent crime, consistent with the prevalence of juvenile-on-juvenile violence. The number of juveniles who report violent victimization by other juveniles decreases by 37 percent on teacher in-service days. However, adults also benefit from in-service days, with a point estimate that indicates the number of adults reporting violent victimizations by juveniles drops by roughly 19 percent on such days (although this coefficient is only marginally significant). This final result is somewhat puzzling in light of our concentration theory, and suggests that there may be additional mechanisms through which school influences juvenile crime.

\subsection{The Heterogeneity of Schooling Effects Across Juvenile Offenders}

Table 13 examines whether the effects of school vary across juvenile offenders. Overall, the sign of the coefficients is invariant to race, age, gender, and residence. Additionally, there appear to be only minor differences in the magnitude of effects across subgroups. The one exception to this is that school appears to have no effect on juvenile property crime for black 
youth. At the risk of over-interpreting the data, these results suggest that the behavior of older offenders is less sensitive to school, which could be the case if high-risk juveniles are more likely to drop out of school. Similarly, if high-risk juveniles are more likely to dropout in larger cities, we might also expect juvenile crime in these cities to be less sensitive to school schedules than in other cities.

\section{Conclusions}

In summary, we find that school appears to reduce the incidence of juvenile property crime by about 15 percent, but increases the level of juvenile violent crime by nearly 30 percent. Our evidence suggests that these effects are not driven by reporting bias and do not simply reflect temporal displacement. These findings are consistent with a theoretical framework in which school provides monitoring, structure, and activities that reduce property crime while at the same time increasing the level of interaction among adolescents, thereby raising the likelihood of violent conflicts.

Our estimates suggest that lengthening the school year by one day will lead to a decrease of 0.29 property crimes and an increase of 0.25 violent crimes in a city with a population of about $120,000 .{ }^{27}$ Given the average reported value of stolen or damaged property in our sample of $\$ 1,088$, the reduction of property crime would result in a savings of approximately $\$ 318$. It is more difficult to denominate the cost of violent crime in monetary terms. Miller, Fisher, and Cohen (2001) present evidence suggesting that the total cost of an assault committed by a juvenile is $\$ 8,515$. This figure includes the direct costs of the offense (e.g. medical care and foregone wages) as well intangible costs such as pain, suffering, and fear. If we use this measure

\footnotetext{
${ }^{27}$ This is calculated by the authors using estimates of the percent effect of school on property and violent crimes that are committed by at least one juvenile along with the average daily number of such offenses in our sample.
} 
as the cost of each violent offense, the violence associated with having school in session another day costs about $\$ 2,170$. In as much as school has a similar effect on unreported crimes, the true figures might be larger. Additionally, there are costs associated with processing these incidents through the criminal justice system. ${ }^{28}$

While this analysis is likely to be of minimal importance for determining the length of the school year or the provision of summer school, ${ }^{29}$ we believe that this analysis provides some valuable insight into the nature and motivation of juvenile crime. Both incapacitation and social interaction models appear to be important determinants of juvenile crime. In particular, it confirms that when juveniles are not provided with structured or monitored activities, they are likely to engage in anti-social behavior that manifests itself in increased property crime. In addition, it suggests that the degree of interaction among youth plays a significant role in the level of juvenile violence. The increase in violent crime induced by school attendance reflects the potentially volatile nature of juvenile interactions.

Furthermore, our findings may have significant ramifications for other youth activities that do not have an explicit educational component, such as midnight basketball or other programs designed primarily to keep youth busy and "off the streets." The increased violence generated by bringing together youth may offset societal gains associated with reduced property

\footnotetext{
${ }^{28}$ It is unclear how one would measure the effect of crime on the offender's taste for future criminal activity or other intangible effects on the perpetrators of crime.

${ }^{29}$ Crime considerations are likely to be second order relative to the cost and benefits of providing schooling. In particular, according to the 2000 Census, about 20 percent of the U.S. population is between the ages of 5 and 19. This means that reducing school by one day in the average city in our sample would reduce human capital acquisition by 24,000 days or 133 school years. At any reasonable rate of return, the effects of school on human capital acquisition are orders of magnitude more important than the effects of school on crime. Though smaller than the human capital effect, the marginal cost of employing teachers another day is also substantially more important than the crime effects of school.
} 
crime. ${ }^{30}$ In general, our findings suggest that summer youth employment programs or smaller, neighborhood based after-school programs, that provide structured activities for adolescents but do not substantially increase their concentration, may be effective ways to reduce juvenile crime.

To our knowledge, this is the first study that looks at the effect of school on the level as well as the timing of juvenile crime. By highlighting the role of concentration as well as incapacitation, we believe that the findings presented above shed light on the nature of juvenile crime and provide some guidance to those developing prevention programs aimed at youth. Finally, the evidence provided in this paper underscores the importance of social interactions in analyzing individual outcomes.

\footnotetext{
${ }^{30}$ To the extent that these programs involve a select group of youth or include components that serve to mitigate negative interactions or foster interpersonal relationship among youth, it is possible that they may not have the same negative effects on violent crime as school.
} 


\section{References}

Allison, Paul D. and Richard P. Waterman (2002). "Fixed-Effects Negative Binomial Models." in Sociological Methodology 2002. Ross M. Stolzenberg, editor. Boston: Basil Blackwell.

Anderson, David (1999). "The Aggregate Burden of Crime." Journal of Law and Economics. 42(2): 611-42.

Anderson, Craig A., Anderson, Kathryn B., Dorr, Nancy, DeNeve, Kristina M., and Flanagan, Mindy. (2000). "Temperature and Aggression." Advances in Experimental Social Psychology 32: 63-133.

Blumstein, Alfred, Jacqueline Cohen, Jeffrey Roth, and Christy Visher, eds. (1986). Criminal careers and "career criminals." Washington, D.C.: National Academy of Sciences.

Bushway, Shawn. The Impact of a Criminal History Record on Access to Legitimate Employment. PhD. Dissertation. Pittsburgh, PA: Carnegie Mellon University; 1996.

Daag, P.K. (1991). The Psychological Sequelae of Therapeutic Abortion-Denied and Completed. American Journal of Psychiatry 148 (5): 578-85.

Freeman, Richard B. (1995). “The Labor Market.” In Crime James Q. Wilson and Joan Petersilia (Eds.) San Francisco: ICS Press, 171-191.

Freeman, Richard B. (1996). "Why Do So Many Young American Men Commit Crimes and What Might We Do About It" Journal of Economic Perspectives 10(1): 25-42.

Freeman, Richard B. (1992). "Crime and the Employment of Disadvantaged Youths." In Peterson, George and Vroman, Wayne, eds. Urban Labor Markets and Job Opportunity. Washington, D.C.: Urban Institute Press.

Gaviria, A. and Raphael, S. (2001). "School-Based Peer Effects and Juvenile Behavior." Review of Economics and Statistics.

Greene, William H. Econometric Analysis_(4 ${ }^{\text {th }}$ Edition). Prentice-Hall, Inc. Upper Saddle River, NJ, 2000.

Grogger, Jeffrey (1992). "Arrests, Persistent Youth Joblessness and Black/White Employment Differentials." Review of Economics and Statistics. 74: 100-106.

Grogger, Jeffrey (1995). "The Effect of Arrests on the Employment and Earnings of Young Men.” Quarterly Journal of Economics 110(1): 51-71. 
Grogger, Jeffrey (1997) "Local Violence and Educational Attainment." Journal of Human Resources 32(4): 659-682.

Grogger, J. (1998). "Market Wages and Youth Crime.” Journal of Labor Economics 16(4): 75691.

Hausman, Jerry, Bronwyn H. Hall, and Zvi Griliches (1984). "Econometric Models for Count Data with an Application to the Patents-R\&D Relationship." Econometrica 52(4): 909-938.

Jacob, Brian and Lefgren, Lars (2002). "The Temporal Displacement of Crime: What the Weather Has to Say.” Working Paper.

Kling, Jeffrey (1999). The Effect of Prison Sentence Length on the Subsequent Employment and Earnings of Criminal Defendants. Princeton University. Discussion Paper in Economics \#208.

Levitt, Steven D. (1998). Juvenile Crime and Punishment. Journal of Political Economy 106 (December): 1156-85.

Levitt, Steven D. and Lance Lochner (2001). The Determinants of Juvenile Crime. In Risky Behavior Among Youths: An Economic Analysis, ed. Jonathan Gruber Chicago, IL: University of Chicago Press.

Lochner, L. (1999). “Education, Work and Crime: Theory and Evidence.” Rochester Center for Economic Research Working Paper No. 465.

Lochner, L. and Moretti, E. (2001). The Effect of Education on Crime: Evidence from Prison Inmates, Arrests and Self-Reports. Working paper.

Lott, John R. (1990). "The Effect of Conviction on the Legitimate Income of Criminals." Economics Letters. 34: 381-5.

Miller, T. R., D. A. Fisher, and M. A. Cohen (2001). "Costs of Juvenile Violence: Policy Implications." Pediatrics. 107(1): e3.

Mocan, H. Naci, and Daniel Rees (1999). Economic Conditions, Deterrence and Juvenile Crime: Evidence from Micro Data. University of Colorado, Denver. Manuscript.

Nagin, Daniel and Joel Waldfogel (1995). "The Effects of Criminality and Conviction on the Labor Market Status of Young British Offenders." International Review of Law and Economics. 15:109-26.

---. (1998). “The Effect of Conviction on Income Through the Life Cycle." International Review of Law and Economics. 18:25-40. 
Needels, Karen (1996). "Go Directly to Jail and Do Not Collect? A Long-Term Study of Recidivism, Employment, and Earnings Patterns Among Prison Releasees." Journal of Research in Crime and Delinquency. 33(4): 471-496.

Sampson, Robert and John Laub (1993). Crime in the Making: Pathways and Turning Points through Life. Cambridge, MA: Harvard University Press.

Sherman, Lawrence W. "The Police.” In Crime, Eds James Q. Wilson and Joan Petersilia. San Francisco, CA: ICS Press, 1997. 327-348.

Snyder, H. N., \& Sickmund, M. (1999). Juvenile offenders and victims: 1999 national report. Washington, DC: Office of Juvenile Justice and Delinquency Programs.

Waldfogel, Joel (1993). The Effect of Criminal Conviction on Income and the Trust "Reposed in the Workmen." The Journal of Human Resources. 29:62-81.

Waldfogel, Joel (1994). "Does Conviction Have a Persistent Effect on Income and Employment?" International Review of Law and Economics. 14: 103-119.

Western, Bruce (2001). "The Impact of Incarceration on Wage Mobility and Inequality." Working paper. Princeton University.

Wilson, James Q. and Richard Herrnstein (1985). Crime and Human Nature. New York: Simon \& Schuster.

Witte, A. D. (1997). "Crime" in J. Behrman and N Stacey, eds. The Social Benefits of Education. University of Michigan Press, Ann Arbor, Chapter 7. 


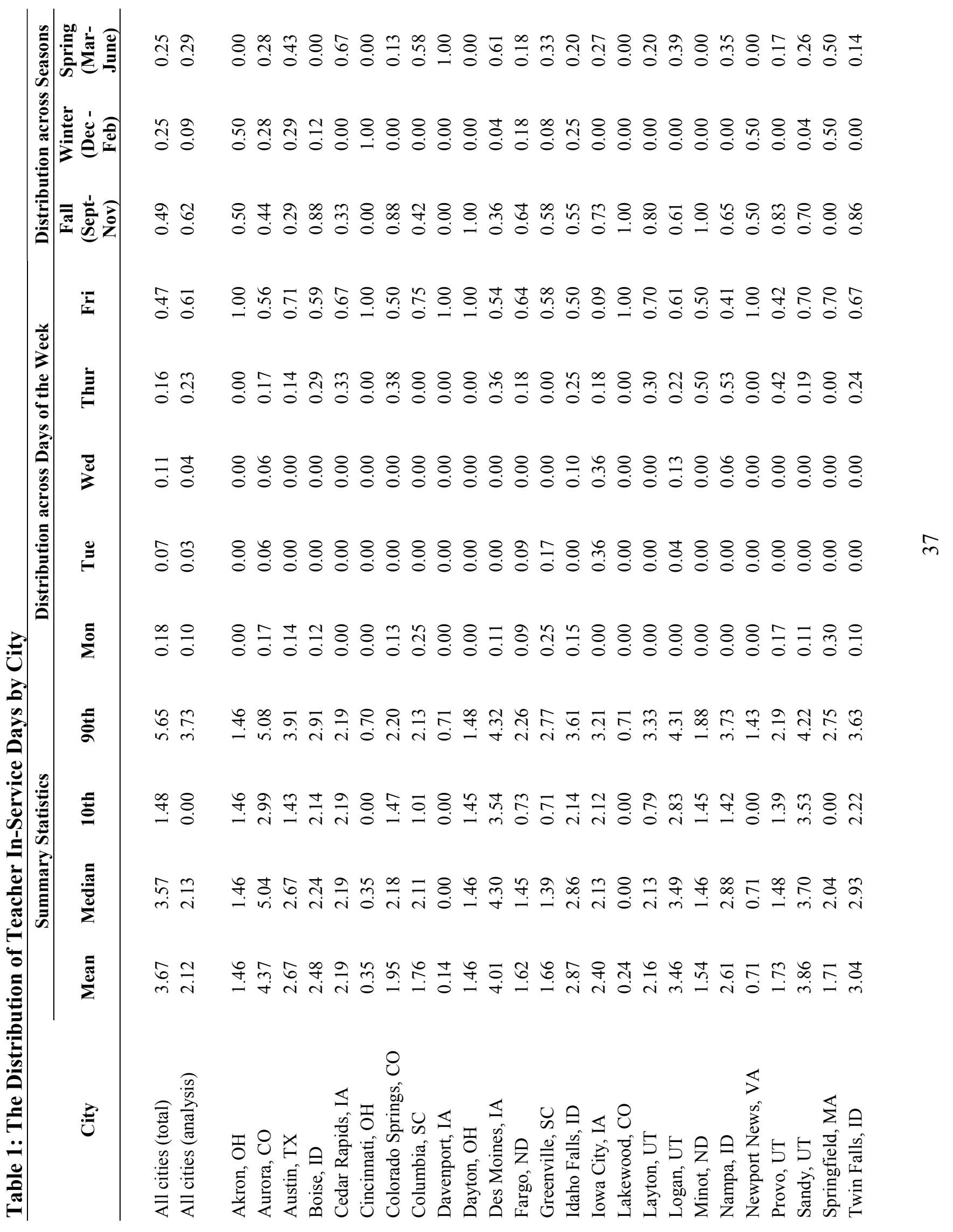




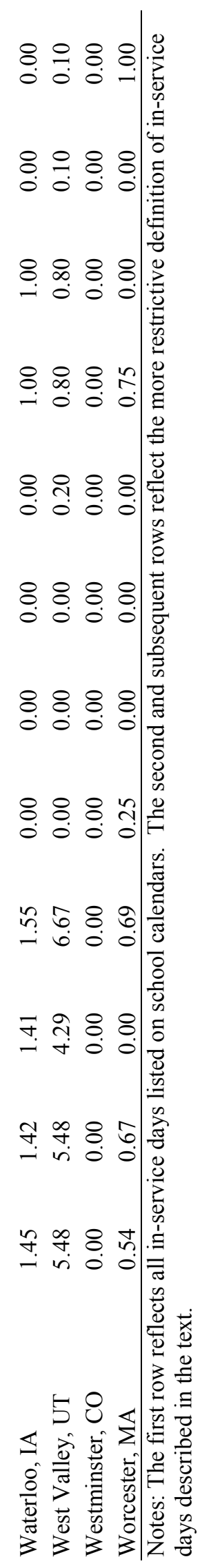


Table 2: Summary Statistics for Jurisdictions in the Sample

\begin{tabular}{|c|c|c|}
\hline Variable & $\begin{array}{c}\text { Analysis } \\
\text { Sample }\end{array}$ & $\begin{array}{c}\text { The } \\
\text { Nation }\end{array}$ \\
\hline \multicolumn{3}{|l|}{ Racial, Age and SES Composition } \\
\hline Fraction White & 0.732 & 0.751 \\
\hline Fraction Back & 0.148 & 0.123 \\
\hline Fraction Hispanic & 0.116 & 0.125 \\
\hline Fraction Asian & 0.028 & 0.036 \\
\hline Fraction single-parent households & 0.085 & 0.072 \\
\hline Fraction of the population $10-19$ & 0.146 & 0.145 \\
\hline \multicolumn{3}{|l|}{ Crime Rate } \\
\hline \multicolumn{3}{|l|}{ Region } \\
\hline Northeast & 0.075 & 0.190 \\
\hline South & 0.233 & 0.356 \\
\hline Midwest & 0.321 & 0.229 \\
\hline West & 0.371 & 0.225 \\
\hline \multicolumn{3}{|l|}{ City Population Size } \\
\hline Average Population Size & 149,414 & -- \\
\hline Population is $<50,000$ & 0.103 & -- \\
\hline Population is $50,000-150,000$ & 0.517 & -- \\
\hline Population is $150,000-300,000$ & 0.276 & -- \\
\hline Population is $300,000-500,000$ & 0.069 & -- \\
\hline Population is $>500,000$ & 0.034 & -- \\
\hline Number of jurisdictions & 29 & -- \\
\hline
\end{tabular}

Notes: The analysis sample contains summary statistics for all of the cities included in our sample. Population figures weight each city equally while all other statistics are population weighted. All information comes from the 2000 Census with the exception of crime rates, which are calculated using data from the 1999 Uniform Crime Reports, compiled by the FBI. 
Table 3: Summary Statistics on Crime and School Sessions in the Analysis Sample

\begin{tabular}{|c|c|c|c|}
\hline Variables & $\begin{array}{c}\text { Mean } \\
(\mathrm{sd})\end{array}$ & $\begin{array}{c}25^{\text {th }} \\
\text { Percentile }\end{array}$ & $\begin{array}{c}75^{\text {th }} \\
\text { Percentile }\end{array}$ \\
\hline \multicolumn{4}{|l|}{ Number of Juvenile Offenders } \\
\hline All Serious Offenses & $\begin{array}{l}5.242 \\
(5.71)\end{array}$ & 1 & 7 \\
\hline Violent Offenses & $\begin{array}{l}1.255 \\
(1.90)\end{array}$ & 0 & 2 \\
\hline Property Offenses & $\begin{array}{l}3.305 \\
(4.20)\end{array}$ & 1 & 5 \\
\hline Other Serious Offenses & $\begin{array}{l}0.681 \\
(1.57)\end{array}$ & 0 & 1 \\
\hline Minor Offenses & $\begin{array}{l}2.146 \\
(3.73)\end{array}$ & 0 & 3 \\
\hline \multicolumn{4}{|l|}{ Number of Adult Offenders } \\
\hline All Serious Offenses & $\begin{array}{c}16.368 \\
(18.23)\end{array}$ & 5 & 22 \\
\hline Violent Offenses & $\begin{array}{l}5.570 \\
(7.17)\end{array}$ & 1 & 8 \\
\hline Property Offenses & $\begin{array}{c}7.667 \\
(8.093)\end{array}$ & 2 & 10 \\
\hline Other Serious Offenses & $\begin{array}{l}3.132 \\
(5.84)\end{array}$ & 0 & 4 \\
\hline Minor Offenses & $\begin{array}{c}8.620 \\
(12.27)\end{array}$ & 2 & 10 \\
\hline \multicolumn{4}{|l|}{ School Session } \\
\hline Teacher In-service & $\begin{array}{c}0.008 \\
(0.089)\end{array}$ & -- & -- \\
\hline Idiosyncratic Breaks & $\begin{array}{c}0.015 \\
(0.121)\end{array}$ & -- & -- \\
\hline Common Breaks & $\begin{array}{c}0.028 \\
(0.164)\end{array}$ & -- & -- \\
\hline National Holidays & $\begin{array}{c}0.031 \\
(0.173)\end{array}$ & -- & -- \\
\hline Summer Vacation & $\begin{array}{c}0.230 \\
(0.421) \\
\end{array}$ & -- & -- \\
\hline Observations & 38,339 & & \\
\hline
\end{tabular}

Notes: This table contains summary statistics for all of the days in our analysis sample. The unit of observation is city*day. 
Table 4: Who are the offenders and victims in juvenile crime?

\begin{tabular}{lcccc}
\hline & \multicolumn{2}{c}{ Violent Crime } & Property Crime & $\begin{array}{c}\text { Other major } \\
\text { crimes }\end{array}$ \\
\cline { 2 - 5 } \multicolumn{1}{c}{ Variable } & Offenders & Victims & Offenders & Offenders \\
\hline \multirow{2}{*}{ Age } & 14.4 & 19.7 & 14.6 & 15.5 \\
& $(2.3)$ & $(12.8)$ & $(2.2)$ & $(1.7)$ \\
Under age 12 & 0.11 & 0.19 & 0.09 & 0.03 \\
& $(0.31)$ & $(0.39)$ & $(0.29)$ & $(0.16)$ \\
Age 12-14 & 0.33 & 0.21 & 0.32 & 0.19 \\
& $(0.47)$ & $(0.41)$ & $(0.47)$ & $(0.40)$ \\
Age 15-17 & 0.56 & 0.21 & 0.59 & 0.78 \\
& $(0.50)$ & $(0.41)$ & $(0.49)$ & $(0.42)$ \\
Age 18-24 & -- & 0.12 & -- & -- \\
Over age 24 & & $(0.33)$ & & -- \\
White & -- & 0.25 & -- & 0.77 \\
& & $(0.43)$ & 0.72 & $(0.42)$ \\
Black & 0.59 & 0.67 & $(0.45)$ & 0.21 \\
& $(0.49)$ & $(0.48)$ & 0.25 & $(0.41)$ \\
Other & 0.39 & 0.27 & $(0.43)$ & 0.02 \\
& $(0.49)$ & $(0.45)$ & 0.03 & $(0.12)$ \\
Male & 0.018 & 0.05 & $(0.16)$ & 0.83 \\
& $(0.13)$ & $(0.22)$ & 0.75 & $(0.38)$ \\
Female & 0.72 & 0.48 & $(0.43)$ & 0.17 \\
& $(0.45)$ & $(0.48)$ & 0.25 & $(0.38)$ \\
\hline Observations & 0.28 & 0.52 & $(0.43)$ & 26,121 \\
\hline Ne & $(0.45)$ & $(0.50)$ & 126,719 &
\end{tabular}

Notes: This table shows the average characteristics of juvenile and adult offenders in our sample. The unit of observation is the juvenile offender. Standard deviations are in parentheses. 
Table 5: What types of crime do juveniles commit most often?

\begin{tabular}{|c|c|}
\hline Serious Offenses & Frequency \\
\hline Shoplifting & 0.202 \\
\hline Simple Assault & 0.149 \\
\hline Vandalism & 0.137 \\
\hline All other larceny & 0.070 \\
\hline Drug Violations & 0.070 \\
\hline Burglary & 0.060 \\
\hline Aggravated assault & 0.047 \\
\hline Motor vehicle theft & 0.037 \\
\hline Theft from motor vehicle & 0.035 \\
\hline Drug equipment violations & 0.033 \\
\hline Theft from building & 0.026 \\
\hline Intimidation & 0.023 \\
\hline Weapons law violation & 0.022 \\
\hline Robbery & 0.021 \\
\hline Stolen property offense & 0.014 \\
\hline Other offenses & 0.054 \\
\hline Total & 1.000 \\
\hline \multicolumn{2}{|l|}{ All Offenses } \\
\hline Shoplifting & 0.144 \\
\hline Simple assault & 0.106 \\
\hline Vandalism & 0.097 \\
\hline All other type B offenses & 0.088 \\
\hline Runaway & 0.069 \\
\hline All other larceny & 0.051 \\
\hline Drug violation & 0.049 \\
\hline Curfew/loitering/vagrancy violation & 0.046 \\
\hline Burglary & 0.043 \\
\hline Aggravated assault & 0.033 \\
\hline Disorderly conduct & 0.032 \\
\hline Liquor law violations & 0.030 \\
\hline Motor vehicle theft & 0.026 \\
\hline Theft from a motor vehicle & 0.025 \\
\hline Drug equipment violations & 0.022 \\
\hline Trespass of real property & 0.020 \\
\hline Other offenses & 0.119 \\
\hline Total & 1.000 \\
\hline
\end{tabular}

Notes: This table shows the relative frequency of each type of offense for juvenile offenders in our analysis sample. These results are computed for crimes for which the age of the offender is known. Serious offenses are defined as NIBRS type A offenses and include primarily property, violent, and drug crimes. Minor offenses are defined as NIBRS type B offenses and include offenses such as trespassing, loitering, disorderly conduct, and liquor law violations. 


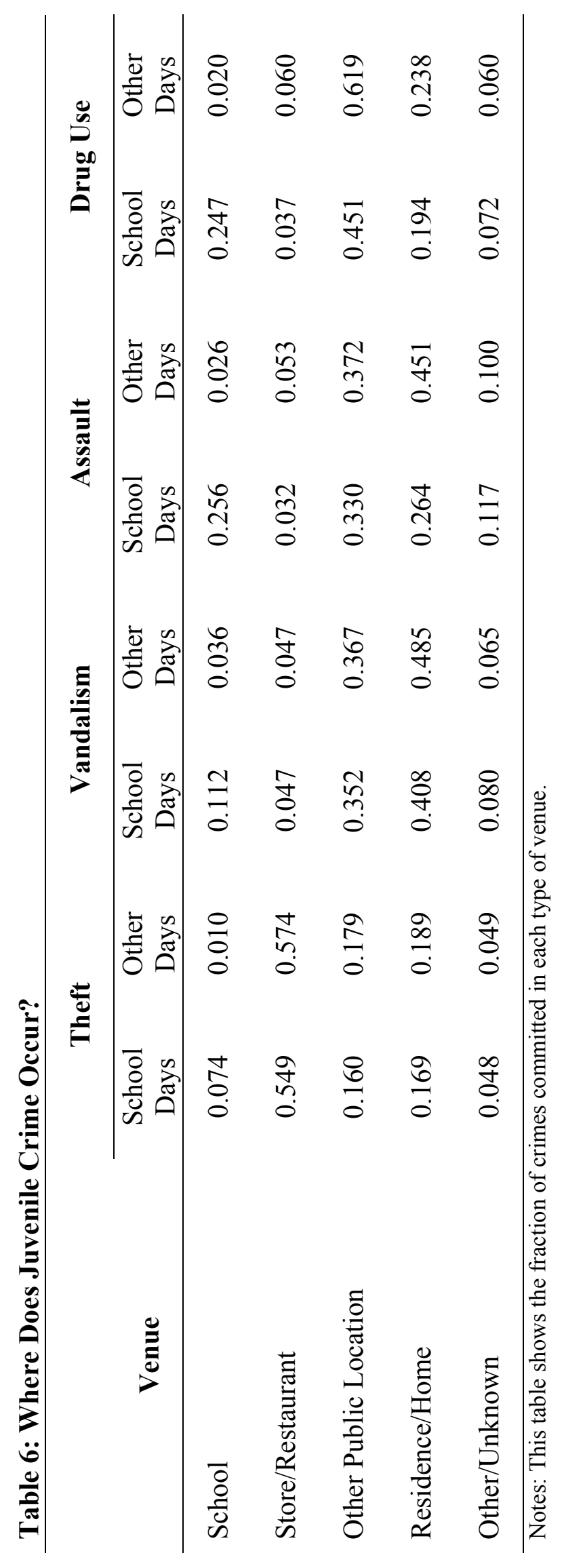




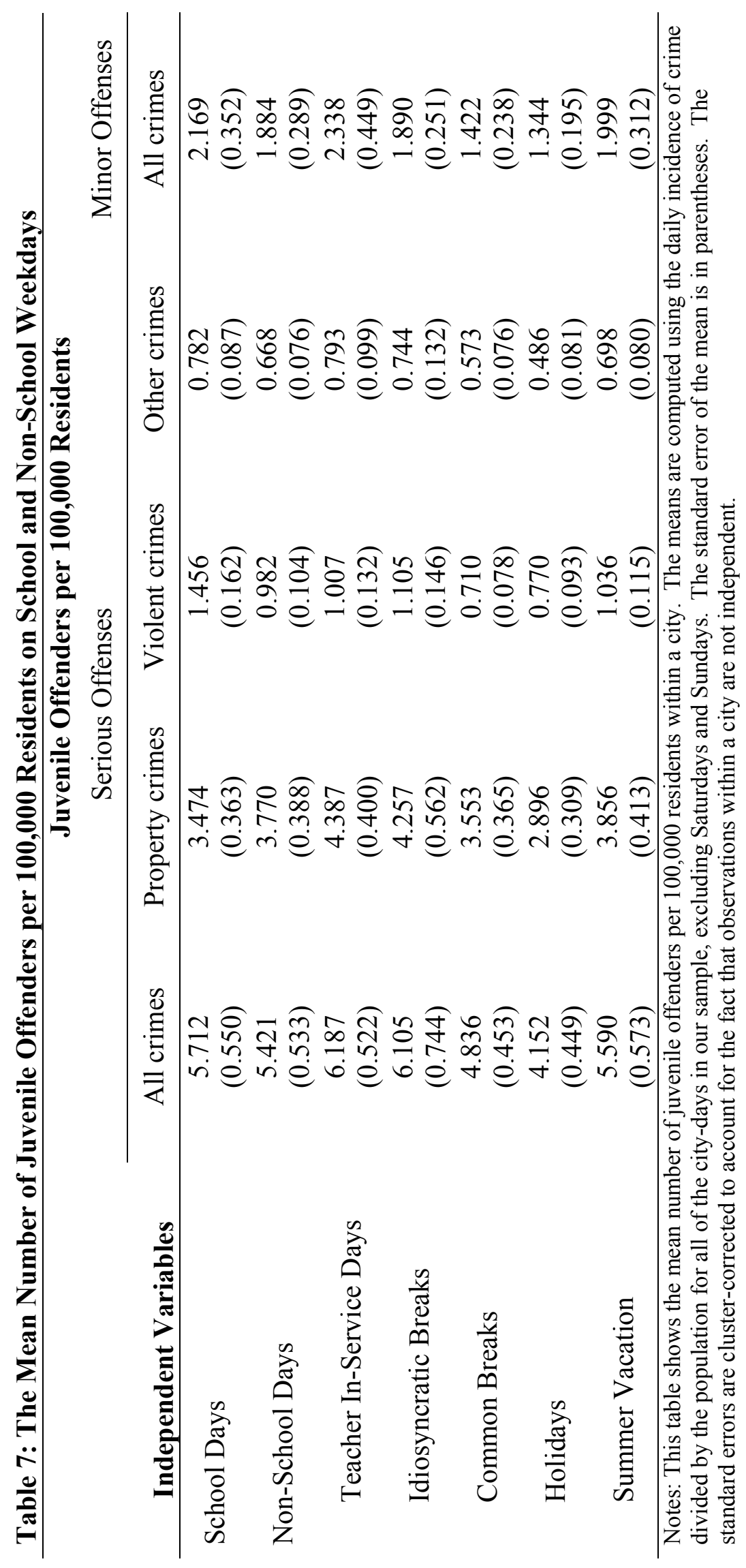


Table 8: The Relationship between Reported Juvenile Offenders and the School Term

\section{Dependent Variable $=$}

Number of reported juvenile offenders for the following offenses

Serious Offenses

\begin{tabular}{|c|c|c|c|c|c|}
\hline \multirow[b]{2}{*}{$\begin{array}{l}\text { Independent } \\
\text { Variables }\end{array}$} & & \multirow{2}{*}{$\frac{\text { Offenses }}{\text { All crimes }}$} \\
\hline & All crimes & $\begin{array}{l}\text { Property } \\
\text { crimes }\end{array}$ & $\begin{array}{l}\text { Violent } \\
\text { crimes }\end{array}$ & $\begin{array}{l}\text { Other } \\
\text { crimes }\end{array}$ & \\
\hline $\begin{array}{l}\text { Teacher in-service } \\
\text { day }\end{array}$ & $\begin{array}{l}-0.007 \\
(0.16)\end{array}$ & $\begin{array}{l}0.133 \\
(2.78)\end{array}$ & $\begin{array}{l}-0.323 \\
(4.40)\end{array}$ & $\begin{array}{l}-0.106 \\
(1.07)\end{array}$ & $\begin{array}{l}-0.153 \\
(2.57)\end{array}$ \\
\hline Idiosyncratic Break & $\begin{array}{l}0.032 \\
(1.02)\end{array}$ & $\begin{array}{l}0.154 \\
(4.17)\end{array}$ & $\begin{array}{l}-0.204 \\
(3.94)\end{array}$ & $\begin{array}{l}-0.089 \\
(1.13)\end{array}$ & $\begin{array}{l}-0.079 \\
(1.77)\end{array}$ \\
\hline Common Break & $\begin{array}{l}-0.112 \\
(4.31)\end{array}$ & $\begin{array}{l}0.021 \\
(0.71)\end{array}$ & $\begin{array}{l}-0.478 \\
(10.00)\end{array}$ & $\begin{array}{l}-0.353 \\
(5.18)\end{array}$ & $\begin{array}{l}-0.271 \\
(6.90)\end{array}$ \\
\hline Holiday & $\begin{array}{c}-0.268 \\
(10.63)\end{array}$ & $\begin{array}{l}-0.179 \\
(6.05)\end{array}$ & $\begin{array}{c}-0.418 \\
(9.85)\end{array}$ & $\begin{array}{l}-0.343 \\
(5.47)\end{array}$ & $\begin{array}{c}-0.388 \\
(10.30)\end{array}$ \\
\hline Summer Vacation & $\begin{array}{l}-0.018 \\
(0.89)\end{array}$ & $\begin{array}{l}0.068 \\
(2.90)\end{array}$ & $\begin{array}{c}-0.220 \\
(6.52)\end{array}$ & $\begin{array}{l}-0.105 \\
(2.60)\end{array}$ & $\begin{array}{l}-0.128 \\
(4.33)\end{array}$ \\
\hline Half Day & $\begin{array}{l}0.172 \\
(3.27)\end{array}$ & $\begin{array}{l}0.156 \\
(2.36)\end{array}$ & $\begin{array}{l}0.101 \\
(1.28)\end{array}$ & $\begin{array}{l}0.159 \\
(1.20)\end{array}$ & $\begin{array}{l}-0.126 \\
(1.43)\end{array}$ \\
\hline Tuesday & $\begin{array}{l}-0.007 \\
(0.52)\end{array}$ & $\begin{array}{l}-0.039 \\
(2.29)\end{array}$ & $\begin{array}{l}0.046 \\
(2.15)\end{array}$ & $\begin{array}{l}0.078 \\
(2.29)\end{array}$ & $\begin{array}{l}0.073 \\
(3.69)\end{array}$ \\
\hline Wednesday & $\begin{array}{l}-0.028 \\
(2.03)\end{array}$ & $\begin{array}{l}-0.060 \\
(3.54)\end{array}$ & $\begin{array}{l}0.045 \\
(2.07)\end{array}$ & $\begin{array}{l}0.031 \\
(0.89)\end{array}$ & $\begin{array}{l}0.043 \\
(2.15)\end{array}$ \\
\hline Thursday & $\begin{array}{l}-0.040 \\
(2.84)\end{array}$ & $\begin{array}{l}-0.061 \\
(3.60)\end{array}$ & $\begin{array}{r}-0.011 \\
(0.52)\end{array}$ & $\begin{array}{l}0.038 \\
(1.12)\end{array}$ & $\begin{array}{l}0.023 \\
(1.14)\end{array}$ \\
\hline Friday & $\begin{array}{l}0.054 \\
(3.94)\end{array}$ & $\begin{array}{l}0.019 \\
(1.16)\end{array}$ & $\begin{array}{l}0.052 \\
(2.39)\end{array}$ & $\begin{array}{l}0.206 \\
(6.17)\end{array}$ & $\begin{array}{l}0.170 \\
(8.71)\end{array}$ \\
\hline Saturday & $\begin{array}{l}-0.071 \\
(5.06)\end{array}$ & $\begin{array}{l}0.029 \\
(1.74)\end{array}$ & $\begin{array}{c}-0.374 \\
(15.60)\end{array}$ & $\begin{array}{c}-0.108 \\
(3.05)\end{array}$ & $\begin{array}{l}-0.052 \\
(2.55)\end{array}$ \\
\hline Sunday & $\begin{array}{c}-0.294 \\
(19.69)\end{array}$ & $\begin{array}{c}-0.243 \\
(13.65)\end{array}$ & $\begin{array}{c}-0.416 \\
(17.15)\end{array}$ & $\begin{array}{r}-0.302 \\
(8.09) \\
\end{array}$ & $\begin{array}{l}-0.212 \\
(9.97) \\
\end{array}$ \\
\hline $\begin{array}{l}\text { City*month*year } \\
\text { and day of week } \\
\text { fixed effects }\end{array}$ & Yes & Yes & Yes & Yes & Yes \\
\hline Observations & 38,339 & 38,339 & 38,308 & 37,181 & 37,451 \\
\hline $\begin{array}{l}\text { Notes: The estimates con } \\
\text { offenses are defined as } \\
\text { offenses are defined as } \\
\text { conduct, and liquor law } \\
\text { Day, Easter, President's } \\
\text { more than } 30 \text { percent of } \\
\text { have off. Teacher in-ser } \\
\text { districts reserve for teach }\end{array}$ & $\begin{array}{l}\text { om negative b } \\
\text { S type A offe } \\
\text { S type B offe } \\
\text { tions. Nation } \\
\text { and Memoria } \\
\text { chool districts } \\
\text { days are days } \\
\text { to attend profe }\end{array}$ & $\begin{array}{l}\text { mial regressio } \\
\text { and include } 1 \\
\text { and include } \\
\text { olidays incluc } \\
\text { y. Idiosyncra } \\
\text { off. Comm } \\
\text { ng the regula } \\
\text { nal developm }\end{array}$ & $\begin{array}{l}\text {-statistics a } \\
\text { irily propert } \\
\text { ses such as } t \\
\text { ys such as T } \\
\text { eaks are da } \\
\text { eaks are day } \\
\text { ool year tha } \\
\text { vorkshops o }\end{array}$ & $\begin{array}{l}\text { uded in par } \\
\text { ent, and dru } \\
\text { sing, loiter } \\
\text { giving, Chr } \\
\text { a school di } \\
\text { more than } \\
\text { nts do not } \\
\text { l-based pla }\end{array}$ & $\begin{array}{l}\text { is. Serious } \\
\text { hes. Minor } \\
\text { sorderly } \\
\text { New Year's } \\
\text { has off and no } \\
\text { cent of schools } \\
\text { school and } \\
\text { activities. }\end{array}$ \\
\hline
\end{tabular}




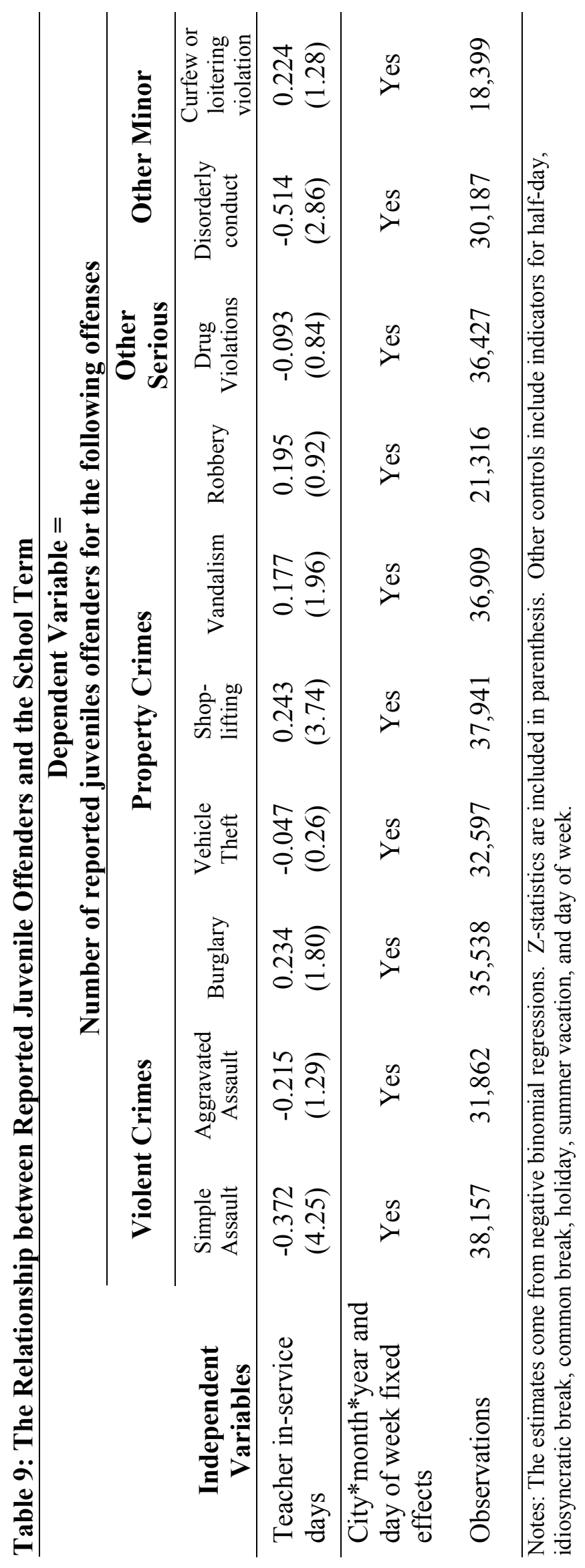




\section{Model I}

Teacher In-Service

1 day preceding in-service

2 days preceding in-service

3 days preceding in-service

1 day following in-service

2 days following in-service

3 days following in-service
0.110

(2.17)

0.079

(1.51)

0.013

$(0.24)$

$-0.092$

(1.69)

$-0.008$

$(0.15)$

$-0.065$

(1.12)

$-0.032$

$(0.61)$
$-0.305$

(4.02)

$-0.045$

$-0.014$

$(0.21)$

$-0.051$

$(0.78)$

$-0.102$

(1.32)

$-0.101$

(1.26)

$-0.079$

Sum of Coefficients

0.006

$-0.697$

Test that sum of coefficients equals zero [p-value]

0.00

16.11

[0.96]

[0.00]

City*month*year and day of week fixed effects

Yes

Yes

Observations (days)

38,339

38,308

\section{Model II}

Fraction of the week consisting of teacher in-service days

Notes: All coefficient estimates come from a negative binomial regression. Z-statistics are shown in parenthesis. In Model I, the regressions include all controls shown in Table 8 as well as indicators for the three days preceding and following school breaks, holidays, and summer vacation. In Model II, the unit of observation is city*week. We define weeks as beginning on Tuesday to center the week around Friday, the modal day for teacher in-service. Months are defined as four-week periods beginning in January, 1995 and therefore do not correspond to actual calendar months. We also control for the fraction of days that are idiosyncratic breaks, common breaks, holidays, and summer days. 
Table 11: Robustness Checks

Dependent Variable

Specification

(Cells contain coefficient estimates of the in-service variable)

\begin{tabular}{|c|c|c|c|}
\hline \multicolumn{4}{|c|}{ Baseline } \\
\hline 1 & Baseline results & $\begin{array}{l}0.133 \\
(2.78)\end{array}$ & $\begin{array}{r}-0.323 \\
(4.40)\end{array}$ \\
\hline \multicolumn{4}{|c|}{ Checking for Reporting Bias } \\
\hline 2 & Examining only aggravated assaults & --- & $\begin{array}{r}-0.215 \\
(1.29)\end{array}$ \\
\hline 3 & $\begin{array}{l}\text { Considering only crimes committed } \\
\text { during non-school hours. }\end{array}$ & $\begin{array}{l}0.123 \\
(2.19)\end{array}$ & $\begin{array}{r}-0.237 \\
(2.64)\end{array}$ \\
\hline & Only considering crimes that do & 0.189 & -0.141 \\
\hline 4 & NOT take place inside school & $(3.91)$ & $(1.81)$ \\
\hline \multicolumn{4}{|c|}{ Determining the Importance of Coordination } \\
\hline 5 & $\begin{array}{l}\text { Using the number of incidents } \\
\text { involving only one juvenile as the } \\
\text { dependent variable }\end{array}$ & $\begin{array}{l}0.146 \\
(3.02)\end{array}$ & $\begin{array}{l}-0.328 \\
(4.30)\end{array}$ \\
\hline 6 & $\begin{array}{l}\text { Using the number of incidents } \\
\text { involving two or more juveniles as } \\
\text { the dependent variable. }\end{array}$ & $\begin{array}{l}0.100 \\
(1.49)\end{array}$ & $\begin{array}{r}-0.211 \\
(1.67)\end{array}$ \\
\hline \multicolumn{4}{|c|}{ Other Robustness Checks } \\
\hline 7 & $\begin{array}{l}\text { Using the incidence of adult crime as } \\
\text { the dependent variable }\end{array}$ & $\begin{array}{l}0.046 \\
(1.49)\end{array}$ & $\begin{array}{l}-0.015 \\
(0.44)\end{array}$ \\
\hline 8 & Controlling for adult crime rate & $\begin{array}{l}0.118 \\
(2.50)\end{array}$ & $\begin{array}{r}-0.318 \\
(4.34)\end{array}$ \\
\hline 9 & $\begin{array}{l}\text { Controlling for mean temperature } \\
\text { and precipitation }\end{array}$ & $\begin{array}{l}0.132 \\
(2.74)\end{array}$ & $\begin{array}{r}-0.334 \\
(4.47)\end{array}$ \\
\hline 10 & $\begin{array}{l}\text { Using the number of juvenile arrests } \\
\text { as the dependent variable }\end{array}$ & $\begin{array}{l}0.068 \\
(1.10)\end{array}$ & $\begin{array}{r}-0.307 \\
(2.94)\end{array}$ \\
\hline 11 & $\begin{array}{l}\text { Using the number of incidents } \\
\text { involving at least one juvenile as the } \\
\text { dependent variable }\end{array}$ & $\begin{array}{l}0.129 \\
(3.17)\end{array}$ & $\begin{array}{l}-0.299 \\
(4.52)\end{array}$ \\
\hline 12 & $\begin{array}{l}\text { Assigning early morning crimes to } \\
\text { the previous day }\end{array}$ & $\begin{array}{l}0.126 \\
(2.63)\end{array}$ & $\begin{array}{l}-0.345 \\
(4.73)\end{array}$ \\
\hline 13 & $\begin{array}{l}\text { Redefining in-service to include in- } \\
\text { service days near holidays }\end{array}$ & $\begin{array}{l}0.152 \\
(3.96)\end{array}$ & $\begin{array}{r}-0.319 \\
(5.35)\end{array}$ \\
\hline 14 & $\begin{array}{l}\text { Combining in-service and } \\
\text { idiosyncratic break variables }\end{array}$ & $\begin{array}{l}0.146 \\
(4.95)\end{array}$ & $\begin{array}{r}-0.245 \\
(5.74)\end{array}$ \\
\hline \multicolumn{4}{|c|}{ Sensitivity to Estimation Technique } \\
\hline 15 & Poisson regression & $\begin{array}{l}0.095 \\
(3.26)\end{array}$ & $\begin{array}{r}-0.291 \\
(5.25)\end{array}$ \\
\hline 16 & $\begin{array}{l}\text { OLS regression-dependent variable } \\
\text { is the number of offenders per } \\
100,000 \text { residents }^{\wedge}\end{array}$ & $\begin{array}{l}0.352 \\
(1.32) \\
{[0.10]}\end{array}$ & $\begin{array}{l}-0.471 \\
(4.24) \\
{[-0.40]}\end{array}$ \\
\hline
\end{tabular}

Notes: The estimates come from negative binomial regressions. Z-statistics are shown in parenthesis. The regressions also include controls for summer vacation, national holidays, idiosyncratic breaks, common breaks, half days and fixed effects for day of week and city*year*month. ${ }^{\wedge}$ The square brackets contain the OLS coefficients divided by the mean crime rate in our sample, which yields effects that are roughly comparable to the baseline coefficients. 
Table 12: The Relationship between Reported Victims of Juvenile Crime and the School Term

\begin{tabular}{|c|c|c|c|c|c|}
\hline \multirow[b]{3}{*}{ Independent Variable } & \multicolumn{5}{|c|}{$\begin{array}{c}\text { Dependent Variable }= \\
\text { Number of Reported Victims of Juvenile Crime }\end{array}$} \\
\hline & \multicolumn{2}{|c|}{ Juvenile Victims } & \multicolumn{2}{|c|}{ Adult Victims } & \multirow{2}{*}{$\begin{array}{l}\text { Institutional } \\
\text { Victims }\end{array}$} \\
\hline & Property & Violent & Property & Violent & \\
\hline Teacher in-service & $\begin{array}{l}0.093 \\
(0.70)\end{array}$ & $\begin{array}{l}-0.371 \\
(4.17)\end{array}$ & $\begin{array}{l}0.157 \\
(2.22)\end{array}$ & $\begin{array}{r}-0.193 \\
(1.77)\end{array}$ & $\begin{array}{l}0.040 \\
(0.81)\end{array}$ \\
\hline $\begin{array}{l}\text { City*month*year and day } \\
\text { of week fixed effects }\end{array}$ & Yes & Yes & Yes & Yes & Yes \\
\hline Observations & 36,452 & 38,065 & 37,336 & 37,549 & 38,339 \\
\hline
\end{tabular}

Notes: The estimates come from negative binomial regressions. Z-statistics are shown in parenthesis. The regressions also include controls for summer vacation, national holidays, idiosyncratic breaks, common breaks, halfdays, and day of week. 
Table 13: The relationship between Juvenile Crime and In-Service Days by Offender Characteristic

\section{Dependent Variable}

Sample Juvenile Property Crimes Juvenile Violent Crimes

$\begin{array}{lll}\text { All Offenders } & 0.133 & -0.323 \\ & (2.78) & (4.40)\end{array}$

By Race of the Offender

White offenders

0.171

$-0.209$

(3.28)

Black offenders

0.019

$-0.529$

(0.19)

By Age of the Offender

Offenders age $15-17$

0.055

$-0.262$

$(0.95)$

Offenders age $12-14$

By Gender of the Offender

Male offenders

0.135

$-0.316$

(2.52)

Female offenders

0.132

$-0.317$

(1.68)

By Residence of the Offender
Population $<120,000$
0.126
$-0.476$
$(0.065)$
(4.13)
0.135
$-0.178$
Population $>120,000$
(2.03)
(1.99)

Notes: The estimates come from negative binomial regressions. Z-statistics are shown in parenthesis. The regressions also include controls for summer vacation, national holidays, idiosyncratic breaks, common breaks, half days and fixed effects for day of week and city*year*month. 
Figure 1: The Timing of Juvenile Crime on School versus Non-School Days
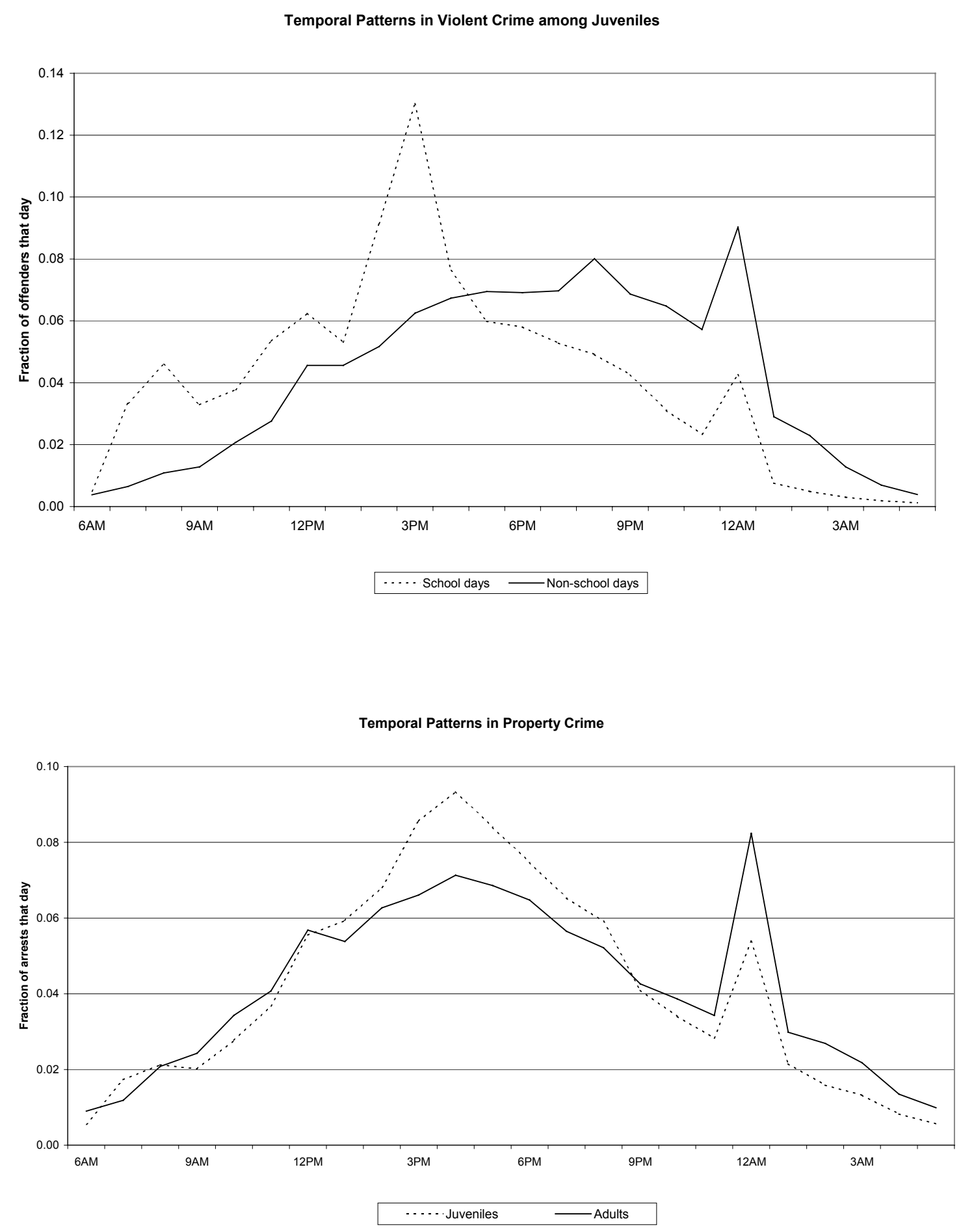
Appendix A: Cities included in the analysis

\begin{tabular}{|c|c|c|}
\hline City & Population & Time in Sample \\
\hline Akron, $\mathrm{OH}$ & 216,620 & Jan 1999-Dec 1999 \\
\hline Aurora, CO & 222,460 & Jan 1997-Dec 1999 \\
\hline Austin, TX & 560,389 & Jan 1998-Dec 1999 \\
\hline Boise, ID & 160,702 & Jan 1999-Dec 1999 \\
\hline Cedar Rapids, IA & 114842 & Jan 1999-Dec 1999 \\
\hline Cincinnati, $\mathrm{OH}$ & 337,815 & Jan 1998-Dec 1999 \\
\hline Colorado Springs, CO & 352,386 & Jan 1997-Dec 1999 \\
\hline Columbia, SC & 112,539 & Jan 1995-Dec 1999 \\
\hline Davenport, IA & 97,078 & Jan 1995-Dec 1999 \\
\hline Dayton, $\mathrm{OH}$ & 168,180 & Jan 1998-Dec 1999 \\
\hline Des Moines, IA & 191,345 & Jan 1995-Dec 1999 \\
\hline Fargo, ND & 86,430 & Jan 1995-Dec 1999 \\
\hline Greenville, SC & 57,168 & Jan 1995-Dec 1999 \\
\hline Iowa City, IA & 61,045 & Aug 1996-Dec 1999 \\
\hline Idaho Falls, ID & 49,023 & Jan 1995-Dec 1999 \\
\hline Lakewood, CO & 139,819 & Jan 1997-Dec 1999 \\
\hline Layton, UT & 55,901 & Sep 1995-Dec 1999 \\
\hline Logan, UT & 40,849 & Jan 1995-Nov 1999 \\
\hline Minot, ND & 35,033 & Jan 1995-Dec 1999 \\
\hline Nampa, ID & 42,737 & Jan 1995-Dec 1999 \\
\hline Newport News, VA & 180,760 & Jul 1998-Dec 1999 \\
\hline Provo, UT & 112,001 & Jan 1995-Dec 1999 \\
\hline Sandy, UT & 100,607 & Jan 1995-Dec 1999 \\
\hline Springfield, MA & 148,820 & Jun 1996-Dec 1999 \\
\hline Twin Falls, ID & 33,920 & Jan 1995-Dec1999 \\
\hline Waterloo, IA & 63,858 & Aug 1996-Dec 1999 \\
\hline West Valley, UT & 100,795 & Aug 1998-Dec 1999 \\
\hline Westminster, $\mathrm{CO}$ & 55,617 & Jan 1997-Dec 1999 \\
\hline Worcester, MA & 167,295 & Jan 1995-Dec 1999 \\
\hline
\end{tabular}

Note: Inclusion in the sample was based on the availability of crime and school calendar data. Among the cities listed, we excluded a small number of months in which it appeared that crimes were not reported systematically. A list of these months is available from the authors. 